\title{
Heritabilities and genetic correlations in the same traits across different strata of herds created according to continuous genomic, genetic, and phenotypic descriptors
}

\author{
Tong Yin and Sven König ${ }^{1}$ \\ Institute of Animal Breeding and Genetics, Justus-Liebig-University of Gießen, 35390 Gießen, Germany
}

\begin{abstract}
The most common approach in dairy cattle to prove genotype by environment interactions is a multiple-trait model application, and considering the same traits in different environments as different traits. We enhanced such concepts by defining continuous phenotypic, genetic, and genomic herd descriptors, and applying random regression sire models. Traits of interest were test-day traits for milk yield, fat percentage, protein percentage, and somatic cell score, considering 267,393 records from 32,707 first-lactation Holstein cows. Cows were born in the years 2010 to 2013, and kept in 52 large-scale herds from 2 federal states of north-east Germany. The average number of genotyped cows per herd $(45,613$ single nucleotide polymorphism markers per cow) was 133.5 (range: 45 to 415 genotyped cows). Genomic herd descriptors were (1) the level of linkage disequilibrium $\left(\mathrm{r}^{2}\right)$ within specific chromosome segments, and (2) the average allele frequency for single nucleotide polymorphisms in close distance to a functional mutation. Genetic herd descriptors were the (1) intra-herd inbreeding coefficient, and (2) the percentage of daughters from foreign sires. Phenotypic herd descriptors were (1) herd size, and (2) the herd mean for nonreturn rate. Most correlations among herd descriptors were close to 0 , indicating independence of genomic, genetic, and phenotypic characteristics. Heritabilities for milk yield increased with increasing intraherd linkage disequilibrium, inbreeding, and herd size. Genetic correlations in same traits between adjacent levels of herd descriptors were close to 1 , but declined for descriptor levels in greater distance. Genetic correlation declines were more obvious for somatic cell score, compared with test-day traits with larger heritabilities (fat percentage and protein percentage). Also, for milk yield, alterations of herd descriptor levels had an obvi-
\end{abstract}

Received July 26, 2017.

Accepted October 25, 2017.

${ }^{1}$ Corresponding author: sven.koenig@agrar.uni-giessen.de ous effect on heritabilities and genetic correlations. By trend, multiple trait model results (based on created discrete herd classes) confirmed the random regression estimates. Identified alterations of breeding values in dependency of herd descriptors suggest utilization of specific sires for specific herd structures, offering new possibilities to improve sire selection strategies. Regarding genomic selection designs and genetic gain transfer into commercial herds, cow herds for the utilization in cow training sets should reflect the genomic, genetic, and phenotypic pattern of the broad population.

Key words: genotype $\times$ environment interactions, test-day production trait, genetic and genomic herd descriptors, random regression model

\section{INTRODUCTION}

The existence of genotype by environment interactions $(\mathbf{G} \times \mathbf{E})$ indicates that different genotypes show different trait reactions in different environments. Obvious $\mathrm{G} \times \mathrm{E}$ imply re-rankings of genotypes in different environments. The physiological background might be that different genes are switched on and off with environmental changes. Such genomic determinants of $\mathrm{G} \times \mathrm{E}$ were also studied via gene expressions (Grishkevich and Yanai, 2013).

The general quantitative-genetic proof for the detection of $\mathrm{G} \times \mathrm{E}$ is based on Falconer's concept (Falconer and Mackay, 1996), that is, defining same traits in different environments as different traits, and applying multiple trait models. As an indicator for a possible $\mathrm{G} \times \mathrm{E}$, Robertson (1959) recommended a genetic correlation threshold of 0.80 . During the past decades, a multiplicity of $\mathrm{G} \times \mathrm{E}$ studies applied the classical multiple trait approach (König et al., 2005). Genetic correlations substantially lower than 0.80 were identified for pronounced differences of production systems within countries [e.g., "grazing" versus "conventional" (Boettcher et al., 2003)], or for extremely diverse countries [e.g., "Kenya" versus "United Kingdom" (Ojango and Pollott, 2002)]. König et al. (2002) stretched this concept by stratifying data according to production 
systems plus considering cow sire characteristics. Cow sire characteristics addressed the sire origin (i.e., the creation of specific data sets only including daughters from foreign proven sires, or proven sires from Germany, or national test bulls). Production systems were defined as family farms from the western (west) versus large-scale farms from the eastern (east) part of Germany. Genetic correlations for protein yield defined in the east and west as different traits were close to 1 for the cow data set from proven sires, but substantially decreased when exclusively considering daughters from test bulls. König et al. (2002) assumed the effect of the size of the data sets (substantially lower number of cows from test bulls), and of genetic connectedness between the data sets, on genetic correlation estimates. Recently, they continued their previous study by creating identical data sets for the different cow sire groups. In this regard, "identical datasets" implied an identical number of cow records, and an equal number and distribution of daughter records per sire category (Table 1). However, the general trend still existed: genetic correlations decreased for an increased herd size in the east region, and the effect was more pronounced in test bull daughters compared with daughters from proven sires (Table 1). One possible explanation might be the effect of selection strategies. In a theoretical approach, Via and Lande (1985) studied G $\times \mathrm{E}$ and additionally considered the type of selection on phenotypic plasticity. Selection itself influenced genetic architectures within populations (Bastiaansen et al., 2012).

Results from $\mathrm{G} \times \mathrm{E}$ studies (Table 1) were the motivation for ongoing research in this regard (i.e., to identify possible effects of genetic or genomic herd or sub-population characteristics on genetic correlations for the same traits recorded in different environments). In the genomic era, the availability of high-throughput genomic SNP marker data from commercial cows allows detailed insight into specific chromosomal regions and genetic architectures. In the German "cow calibration group" project for Holstein cows (Yin and König, 2016), more than 20,000 cows from large-scale herds have been genotyped on a 50K SNP platform. For this data structure, Naderi et al. (2016) identified the effect of disease incidences in cow training sets on accuracies of genomic predictions. In consequence, they suggested a training set composition reflecting disease incidences in the broad population.

Random regression or reaction norm methodology was applied to study the effect of continuous environmental herd descriptors or phenotypic herd means on genetic (co)variance components. For example, $\mathrm{G} \times \mathrm{E}$ for production and functional traits were identified along gradients for within-herd temperature-humidity indices (Brügemann et al., 2011, 2013), or when considering mean values for the intra-herd BCS (Calus and Veerkamp, 2003). In the genomic era, random regression models or reaction norm models were enhanced by modeling genomic instead of pedigree relationships (Yin et al., 2014), by incorporating one-step methodology (Tsuruta et al., 2015), and by estimating intercept and slope of the regression line using SNP marker data (Streit et al., 2013; Nguyen et al., 2016). So far, availability of genomic marker data on an animal level enhanced statistical modeling. Furthermore, on a herd level, genetic and genomic characteristics of herds included in cow training sets might influence (1) genetic (co)variance components between the 2 strata of data (training set and remaining population), and in conse-

Table 1. Structure of the data and genetic correlations for protein yield between strata of the data for 305-d lactation protein yield ${ }^{1}$

\begin{tabular}{|c|c|c|c|c|c|c|c|c|c|}
\hline \multicolumn{2}{|c|}{ Region } & \multirow{2}{*}{$\begin{array}{l}\text { Sire } \\
\text { category }\end{array}$} & \multicolumn{2}{|c|}{ No. of cows } & \multirow{2}{*}{$\begin{array}{c}\text { No. of } \\
\text { sires in } \\
\text { common }\end{array}$} & \multicolumn{2}{|c|}{$\begin{array}{l}\text { Average no. of daughters } \\
\text { of sires in common }\end{array}$} & \multirow[b]{2}{*}{$\mathrm{r}_{\mathrm{g}}$} & \multirow[b]{2}{*}{ Reference } \\
\hline A & B & & Region A & Region B & & Region A & Region B & & \\
\hline West & East & All & 43,926 & 94,335 & 586 & 51 & 91 & 0.93 & $\mathrm{~A}$ \\
\hline West & East & Proven & 26,149 & 77,414 & 247 & 81 & 169 & 0.96 & B \\
\hline West & East & Test bull & 9,054 & 11,556 & 119 & 42 & 2 & 0.88 & B \\
\hline West & East $^{>150}$ & All & 43,926 & 34,368 & 291 & 68 & 65 & 0.87 & $\mathrm{~A}$ \\
\hline West & East & All & 7,013 & 7,004 & 100 & 31 & 12 & 0.91 & C \\
\hline West & East & Proven & 7,000 & 6,996 & 100 & 31 & 12 & 0.95 & $\mathrm{C}$ \\
\hline West & East & Test bull & 7,011 & 7,003 & 100 & 31 & 12 & 0.84 & $\mathrm{C}$ \\
\hline West & East $^{>150}$ & All & 4,500 & 4,497 & 291 & 13 & 6 & 0.84 & $\mathrm{C}$ \\
\hline West & East $^{>150}$ & Proven & 4,499 & 4,506 & 161 & 13 & 6 & 0.88 & $\mathrm{C}$ \\
\hline West & East $^{>150}$ & Test bull & 4,502 & 4,501 & 85 & 13 & 6 & 0.74 & $\mathrm{C}$ \\
\hline
\end{tabular}

${ }^{1}$ West and east denote regions (states) from western and eastern Germany; East ${ }^{>150}$ denotes large-scale herds with at least 150 cows from first lactation per herd-calving year.

${ }^{2}$ A: König et al. (2005); B: König et al. (2002); C: König (2017). 
quence, (2) genomic prediction accuracies. The level of relationships between training and testing sets was one important parameter influencing genomic prediction accuracies (e.g., Habier et al., 2010; Clark et al., 2012; Pszczola et al., 2012). However, differences in prediction accuracies and genetic parameter estimates were observed when either using pedigree- or genomic-based relationship matrices (Veerkamp et al., 2011).

In consequence, in the present study, we used phenotypes and high-throughput genotypes (50K SNP chip panel) from cows kept in large-scale contract herds to create herd descriptors on phenotypic (herd size and nonreturn rate), genetic (inbreeding and daughter percentage from foreign sires), and genomic [level of linkage disequilibrium (LD) and allele frequencies] scales. The aims of this study were (1) to estimate genetic parameters in dependency of herd descriptors, and (2) to estimate genetic correlations in same traits across herd descriptor levels. Results indicate the effect of herd characteristics on quantitative-genetic (co)variance components and breeding values in the context of possible $\mathrm{G} \times \mathrm{E}$, with practical relevance when selecting cow herds for their use in cow calibration groups.

\section{MATERIALS AND METHODS}

\section{Cow Traits}

The test-day data set consisted of 267,393 records from 32,707 first lactation Holstein cows, born in 2010 to 2013. Test-day traits included milk yield (MY), fat percentage (fat\%), protein percentage (Pro\%), and SCS. For all test-day traits, cows had at least 3 repeated measurements. Descriptive statistics for the test-day traits are listed in Table 2. Cows were from 52 largescale herds, located within 2 federal states of north-east Germany. Herd size ranged from 246 to 2,067 cows, with an average of 654.14 cows per herd. The average number of records per contemporary group (herd-testday) was 139.41 . The 32,707 cows were daughters from 681 sires, indicating an average of 48.03 daughters per sire. The daughter distribution within sires was as follows: 150 sires had 2 to 10 daughters, 332 sires had 11 to 40 daughters, 149 sires had 41 to 100 daughters, and 50 sires had more than 100 daughters. The most influ- ential sire had 938 daughters. Each sire had daughter records in at least 2 different herds.

\section{Herd Descriptors}

Genomic Herd Descriptors. Genotyping was performed with the Illumina Bovine 50K SNP BeadChip V2 (applied to 4,569 cows; Illumina, San Diego, CA), and with the Illumina Bovine Eurogenomics 10K low density chip (applied to 2,047 cows). The low density genotypes were imputed to the $50 \mathrm{~K}$ panel as used in the national official German genomic evaluations, resulting in 45,613 SNP for all animals. The average number of genotyped cows per herd was 133.5, ranging from 45 to 415 genotyped cows.

$\boldsymbol{L} \boldsymbol{D}$. The level of LD between all possible SNP pairs within $25 \mathrm{~kb}$ windows was calculated based on pairwise $\mathrm{r}^{2}$ (Hill and Robertson, 1968), and applying the PLINK software package (Purcell et al., 2007). Intra-herd $r^{2}$ was the average $\mathrm{r}^{2}$ from all SNP pairs, considering (1) the genotyped cows in the respective herd, and (2) SNP with a minor allele frequency of 0.05 within the $25-\mathrm{kb}$ window. First, we focused on 397 SNP within the 40- to $60-\mathrm{Mbp}$ segment on chromosome $6\left(\mathbf{r}_{\mathrm{chr} 6}{ }^{2}\right)$, because in a meta-analysis (Khatkar et al., 2004), QTL in this region contributed with significant effects on milk yield, fat yield, protein yield, fat percentage, and protein percentage. Second, we calculated intra-herd $\mathrm{r}^{2}$ based on $786 \mathrm{SNP}$ within the 0 to $40 \mathrm{Mbp}$ segment on chromosome $14\left(\mathbf{r}_{\text {chr14 }}{ }^{2}\right)$, to consider LD in the DGAT1 region (Thaller et al., 2003).

Allele Frequency. We calculated the intra-herd allele frequency $(\boldsymbol{p})$ for one specific SNP (ARS-BFGL$N G S$-4939) located on chromosome 14. The exact position for this SNP is at 1,801,116 bp in the DGAT1 gene (Jiang et al., 2010; Minozzi et al., 2013). The DGAT1 gene start and end positions are 1,795,351 and 1,804,562 bp on chromosome 14 . The DGAT1 K232A polymorphism explained $50 \%$ of the genetic variance for fat percentage (Schennink et al., 2007). Accordingly, there is selection pressure on the DGAT1 gene, with different intensity and with different direction in different herds. Selection itself has a strong effect on the $A R S-B F G L$ $N G S-4939$ allele frequency. Allele frequency changes might influence selection response.

Table 2. Descriptive statistics for test-day traits

\begin{tabular}{lccrrrr}
\hline Trait & No. of records & No. of cows & Mean & SD & Minimum & Maximum \\
\hline Milk yield (kg) & 267,393 & 32,707 & 29.71 & 6.35 & 2.00 & 67.20 \\
Fat percentage (\%) & 267,393 & 32,707 & 3.89 & 0.67 & 1.60 & 10.31 \\
Protein percentage (\%) & 267,393 & 32,707 & 3.36 & 0.33 & 2.03 & 6.86 \\
SCS & 266,849 & 32,620 & 2.38 & 1.59 & -3.64 & 9.64 \\
\hline
\end{tabular}


Table 3. Descriptive statistics for the continuous herd descriptors

\begin{tabular}{|c|c|c|c|c|c|}
\hline Herd descriptor & Mean & $\mathrm{SD}$ & $\mathrm{CV}$ & Minimum & Maximum \\
\hline $\mathrm{r}^{2}$ on chromosome 14 between 0 and $40 \mathrm{Mbp}\left(\mathrm{r}_{\operatorname{chr} 14}{ }^{2}\right)$ & 0.31 & 0.01 & 0.03 & 0.29 & 0.36 \\
\hline Percentage of cows with a non-European Union sire (sire\%) & 0.10 & 0.08 & 0.80 & 0.00 & 0.39 \\
\hline Herd size (HS) & 654.14 & 391.51 & 0.60 & 246 & 2,067 \\
\hline Nonreturn rate after 56 d (NRR56) & 0.50 & 0.07 & 0.14 & 0.35 & 0.68 \\
\hline
\end{tabular}

\section{Genetic Herd Descriptors}

Inbreeding Coefficient. Intra-herd pedigree-based inbreeding coefficients $(\boldsymbol{F})$ were calculated using the software package CFC (Sargolzaei et al., 2006). We considered all of the 1,292,113 animals in the pedigree file when calculating the inbreeding coefficients of the 32,707 active cows.

Percentage of Cows with a Non-European Union Sire. We calculated the percentage of cows with a non-European Union (EU) sire in each herd (sire\%) based on sire origin information from national genetic evaluation databases. Non-EU sires mostly included Holstein sires from the United States and Canada (95\% of the non-EU sires). Among the 681 sires, 77 non-EU sires were from the United States, 15 non-EU sires were from Canada, and 1 non-EU sire was from Australia. The remaining sires were from European countries, especially Germany.

\section{Phenotypic Herd Descriptors}

Herd Size. We considered cows from calving years 2010 to 2013 for the calculation of intra-herd herd sizes (HS).

Nonreturn Rate After $\mathbf{5 6} \boldsymbol{d}$. We characterized herds on a continuous phenotypic "cow trait scale" via herd means for nonreturn rates after 56 d (NRR56) from the calving years 2010 to 2013 . Nonreturn rate as a phenotypic descriptor reflects the effect of natural selection, which occurred in female fertility traits rather than in production traits (Bishop, 1964).

Descriptive statistics for all herd descriptors are given in Table 3. To prepare data for the multiple trait approach, we grouped herds into distinct classes according to their herd descriptor means. For all herd descriptors $\left(\mathrm{r}_{\text {chr6 }}{ }^{2}, \mathrm{r}_{\text {chr14 }}{ }^{2}, p, F\right.$, sire\%, HS, and NRR56), we created 3 groups, defined as small, middle, and high. We ordered herds according to herd descriptors, and we allocated an equal number of herds to small, middle, and high; the small group included the first 17 herds with the smallest value for the respective descriptor, middle represented herds from rank 18 to rank 33, and the remaining 17 herds with the largest means were considered in the high herd group. In a random herd allocation scenario (random), herds randomly received consecutive numbers from 1 to 52 . According to the assigned random numbers, herds were allocated to small, middle, or high. We used 50 replicates for the random herd number allocations. Hence, presented genetic parameters were averages from the 50 replicates, along with corresponding standard deviation.

\section{Statistical Models}

Two different statistical models based on the AIREML algorithm as implemented in the DMU package (Madsen and Jensen, 2013). The first model was a random regression sire model (RRM), using the herd means for $\mathrm{r}_{\text {chr6 }} 2, \mathrm{r}_{\text {chr14 }}{ }^{2}, p, F$, sire\%, HS, and NRR56 as continuous descriptors. In matrix notation, the RRM was defined as follows:

$$
\mathbf{y}=\mathbf{X b}+\mathbf{Z u}+\mathbf{W} \mathbf{p}+\mathbf{e},
$$

where $\mathbf{y}$ was a vector of records for test-day traits; $\mathbf{b}$ was a vector of fixed effects including herd-test-day, fixed regressions on age at first calving (in month) modeled with Legendre polynomials of order 3, and fixed regressions on DIM also modeled with Legendre polynomials of order 3 ; $\mathbf{u}$ was a vector of random regression coefficients for additive-genetic sire effects modeled with linear regressions for the continuous herd descriptors (consecutive runs for the different herd descriptors); $\mathbf{p}$ was a vector of permanent environmental effects for the cows; and e was a vector of random residual effects. $\mathbf{X}, \mathbf{Z}$, and $\mathbf{W}$ were incidence matrices for $\mathbf{b}, \mathbf{u}$, and p, respectively. Random effects were assumed to follow a normal distribution with zero means. The variancecovariance structure for random effects was

$$
\operatorname{var}\left[\begin{array}{c}
\mathbf{u} \\
\mathbf{p} \\
\mathbf{e}
\end{array}\right]=\left[\begin{array}{ccc}
\mathbf{G} \otimes \mathbf{A}_{\mathbf{u}} & 0 & 0 \\
0 & \boldsymbol{\sigma}_{\mathbf{p}}^{2} \mathbf{I}_{\mathbf{p}} & 0 \\
0 & 0 & \boldsymbol{\sigma}_{\mathbf{e}}^{2} \mathbf{I}_{\mathbf{n}}
\end{array}\right],
$$


where $\mathbf{G}$ was a $2 \times 2$ (co)variance matrix of random regression coefficients for the additive genetic effect; $\mathbf{A}_{\mathrm{u}}$ was an additive genetic relationship matrix for sires; $\boldsymbol{\sigma}_{\mathbf{p}}^{2}$ and $\boldsymbol{\sigma}_{\mathrm{e}}^{2}$ were variances for the permanent environmental and residual effect, respectively; $\mathbf{I}_{\mathbf{p}}$ and $\mathbf{I}_{\mathbf{n}}$ were identity matrices for $p$ cows and $n$ observations, respectively; and $\otimes$ denotes the Kronecker product.

Second, we applied multiple trait repeatability sire models (MTRM). Following the concept by Falconer and Mackay (1996), we defined same traits recorded in different herd descriptor groups as different traits. Accordingly, we assumed nonexisting phenotypic and residual covariances among traits, because the same cow only represented one herd descriptor class.

In matrix notation, the MTRM including the 3 traits was

$$
\left[\begin{array}{l}
\mathbf{y}_{1} \\
\mathbf{y}_{2} \\
\mathbf{y}_{3}
\end{array}\right]=\left[\begin{array}{l}
\mathbf{X}_{1} \mathbf{b}_{1}+\mathbf{Z}_{1} \mathbf{u}_{1}+\mathbf{W}_{1} \mathbf{p}_{1}+\mathbf{e}_{1} \\
\mathbf{X}_{2} \mathbf{b}_{2}+\mathbf{Z}_{2} \mathbf{u}_{2}+\mathbf{W}_{2} \mathbf{p}_{2}+\mathbf{e}_{2} \\
\mathbf{X}_{3} \mathbf{b}_{3}+\mathbf{Z}_{3} \mathbf{u}_{3}+\mathbf{W}_{3} \mathbf{p}_{3}+\mathbf{e}_{3}
\end{array}\right]
$$

where $\mathbf{y}_{1}, \mathbf{y}_{\mathbf{2}}$, and $\mathbf{y}_{\mathbf{3}}$ were vectors of test-day records for small, middle, and high, respectively; $\mathbf{b}_{1}, \mathbf{b}_{2}$, and $\mathbf{b}_{3}$ were vectors of fixed effects for the 3 traits including the same fixed effects as specified in the RRM (apart from the continuous herd descriptor); $\mathbf{u}_{1}, \mathbf{u}_{2}$, and $\mathbf{u}_{3}$ were vectors of additive-genetic sire effects for the 3 traits; $\mathbf{p}_{1}, \mathbf{p}_{2}$, and $\mathbf{p}_{3}$ were vectors of permanent environmental effects for the cows in the 3 data sets; and $\mathbf{e}_{1}$, $\mathbf{e}_{2}$, and $\mathbf{e}_{3}$ were vectors for the corresponding residual effects. $\mathbf{X}_{1}, \mathbf{X}_{2}, \mathbf{X}_{3}, \mathbf{Z}_{1}, \mathbf{Z}_{2}, \mathbf{Z}_{3}, \mathbf{W}_{1}, \mathbf{W}_{2}$, and $\mathbf{W}_{3}$ were incidence matrices for $\mathbf{b}_{1}, \mathbf{b}_{2}, \mathbf{b}_{3}, \mathbf{u}_{1}, \mathbf{u}_{2}, \mathbf{u}_{3}, \mathbf{p}_{1}, \mathbf{p}_{2}$, and $\mathbf{p}_{3}$, respectively. The variance-covariance structure for random effects was as follows:

$\operatorname{var}\left[\begin{array}{c}\mathbf{u}_{1} \\ \mathbf{u}_{2} \\ \mathbf{u}_{3} \\ \mathbf{p}_{1} \\ \mathbf{p}_{2} \\ \mathbf{p}_{3} \\ \mathbf{e}_{1} \\ \mathbf{e}_{2} \\ \mathbf{e}_{3}\end{array}\right]=\left[\begin{array}{ccccccccc}\mathbf{g}_{11} \mathbf{A} & \mathbf{g}_{12} \mathbf{A} & \mathbf{g}_{13} \mathbf{A} & 0 & 0 & 0 & 0 & 0 & 0 \\ \mathbf{g}_{21} \mathbf{A} & \mathbf{g}_{22} \mathbf{A} & \mathbf{g}_{23} \mathbf{A} & 0 & 0 & 0 & 0 & 0 & 0 \\ \mathbf{g}_{31} \mathbf{A} & \mathbf{g}_{32} \mathbf{A} & \mathbf{g}_{33} \mathbf{A} & 0 & 0 & 0 & 0 & 0 & 0 \\ 0 & 0 & 0 & \mathbf{\sigma}_{\mathbf{p}_{1}}^{2} \mathbf{I}_{\mathbf{p}_{1}} & 0 & 0 & 0 & 0 & 0 \\ 0 & 0 & 0 & 0 & \mathbf{\sigma}_{\mathbf{p}_{2}}^{2} \mathbf{I}_{\mathbf{p}_{2}} & 0 & 0 & 0 & 0 \\ 0 & 0 & 0 & 0 & 0 & \mathbf{\sigma}_{\mathbf{p}_{3}}^{2} \mathbf{I}_{\mathbf{p}_{3}} & 0 & 0 & 0 \\ 0 & 0 & 0 & 0 & 0 & 0 & \mathbf{r}_{11} & 0 & 0 \\ 0 & 0 & 0 & 0 & 0 & 0 & 0 & \mathbf{r}_{22} & 0 \\ 0 & 0 & 0 & 0 & 0 & 0 & 0 & 0 & \mathbf{r}_{33}\end{array}\right]$,

where $\mathbf{g}_{11}, \mathbf{g}_{22}$, and $\mathbf{g}_{33}$ were additive-genetic sire effects for the 3 traits; $\mathrm{g}_{12}$ and $\mathrm{g}_{21}$ were additive genetic covariances for sire effects between traits in small and middle; $\mathrm{g}_{13}$ and $\mathrm{g}_{31}$ were additive-genetic covariances for sire effects between traits in small and high; $\mathbf{g}_{23}$ and $\mathrm{g}_{32}$ were additive-genetic covariances for sire effects between traits in middle and high; $\sigma_{\mathrm{p}_{1}}^{2}, \sigma_{\mathrm{p}_{2}}^{2}$, and $\sigma_{\mathrm{p}_{3}}^{2}$ were the variances for permanent environmental cow effects for the 3 traits; $\mathbf{I}_{\mathbf{p}_{1}}, \mathbf{I}_{\mathbf{p}_{2}}$, and $\mathbf{I}_{\mathbf{p}_{3}}$ were identity matrices for the cows with records for the 3 traits; and $\mathbf{r}_{11}, \mathbf{r}_{22}$, and $\mathbf{r}_{33}$ were residual variances for the 3 traits.

\section{RESULTS AND DISCUSSION}

\section{Characteristics of Herd Descriptors}

Averaged $r^{2}$ for the segment on chromosome 6 was 0.28 , and 0.31 within the segment on chromosome 14 , both with small SD of 0.01 (Table 3 ). A small range for intra-herd LD for the 52 herds from the same region indicates a similar breeding history. The slightly higher $\mathrm{r}^{2}$ in the DGAT1 region compared with the average $\mathrm{r}^{2}$ of pairwise SNP within a $25 \mathrm{~kb}$ distance across the whole genome is due to intensive selection on milk production traits in the past decades (Grisart et al., 2002). For the whole genome, Qanbari et al. (2010) reported a slightly larger average $r^{2}$ value for a German Holstein sub-population, but their analysis based on intensively pre-selected potential bull dams and bull sires. Intraherd $\mathrm{r}_{\text {chr14 }}{ }^{2}$ within the DGAT1 segment was moderately correlated with intra-herd $\mathrm{r}_{\mathrm{chr} 6}{ }^{2}(0.41$; Table 4). Nevertheless, among all herd descriptors, this was one of the strongest associations. The correlation coefficient was slightly larger (0.47) between intra-herd $\mathrm{r}_{\text {chr14 }}{ }^{2}$ and the intra-herd inbreeding coefficient. The correlation of 0.25 between $\mathrm{r}_{\text {chr } 6}{ }^{2}$ and $F$ also reflects the effect of selection on genomic architecture characteristics. In analogy to intra-herd $\mathrm{r}^{2}$-values, intra-herd inbreeding coefficients varied within a small range from 0.04 to 0.05 (Table $3)$. Hence, inbreeding in the sub-population including only 52 herds from a specific region in the eastern part of Germany does not reflect the broader variation of within-herd inbreeding as identified in the former west Germany (König and Simianer, 2006).

Intra-herd allele frequencies for the SNP located in the DGAT1 gene were in a broader range from 0.61 to 0.82. Also for this genomic herd descriptor, the coefficient of variation was quite small (0.05). Nevertheless, the allele frequency variations across herds depict the different production trait selection strategies, that is, a fraction of herds with a stronger focus on an allele A (increasing milk yield, but decreasing fat percentage), and other herds favoring the opposite allele B (decreasing milk yield, but increasing fat percentage). The correlation coefficient between $p$ and $\mathrm{r}_{\text {chrl } 14}{ }^{2}$ was 0.28 . The negative correlation between NRR56 and $F$ $(-0.27)$ was in line with previous findings by Cassell et al. (2003), who argued that increasing inbreeding accumulates harmful recessive alleles in the progenies. 
Correlations were weak among the remaining herd descriptors. This is especially true when correlating phenotypic herd descriptors reflecting the herd environment (HS) or the herd management (NRR56) with genomic descriptors. The generally weak to moderate correlations indicate independence among genomic, genetic, and phenotypic characteristics. Low antagonistic correlations were identified between NRR56 with LD descriptors (i.e., -0.14 with $\mathrm{r}_{\text {chr6 } 6}{ }^{2}$ and -0.17 with $\mathrm{r}_{\mathrm{chr} 6}{ }^{2}$ ). Hence, a better intra-herd nonreturn rate was associated with a lower level of LD. In such a context [i.e., assuming the effect of selection intensity on the LD structure (Pimentel et al., 2013)], antagonistic correlations between production and female fertility traits were especially identified in Holstein herds, which were intensively selected for milk yield over decades (König et al., 2008). In contrast, in the dual-purpose cattle population Deutsches Schwarzbuntes Niederungsrind (the founder population for Holstein, limited selection on milk yield), levels of LD were lower than in the Holstein population, and correlations between MY and fertility were close to zero (Jaeger et al., 2016).

\section{Genetic Parameters for Test-Day Traits on Continuous Herd Descriptor Scales/Within Herd Descriptor Classes}

Genomic Herd Descriptors. With regard to $\mathrm{r}_{\text {chr } 6}{ }^{2}$, and considering the narrow herd interval from 0.25 to 0.32, heritabilities for test-day traits SCS and Pro\% were quite stable (Figure 1A). As expected, among all traits, heritabilities were lowest in the range from 0.10 to 0.12 for the functional trait SCS. Only a minor effect of $\mathrm{r}_{\text {chr6 }}{ }^{2}$ on heritabilities for SCS was assumed, because identified QTL in this region (Khatkar et al., 2004) indicate intensified selection on milk volume and content traits Pro\% and fat\%, but not on low heritability SCS. Accordingly, we observed an obvious effect of intra-herd $\mathrm{r}_{\text {chr6 }}{ }^{2}$ on heritabilities for MY and fat\% [i.e., a heritability increase with $\mathrm{r}_{\text {chr6 }}{ }^{2}>0.29$ (Figure 1A)]. Theoretically, larger LD between markers represents that markers are closely linked among each other, and that those markers (same genetic variants) are transmitted from parents to offspring (Falconer and Mackay, 1996). In consequence, the heritability increase for MY and fat\% with increasing $\mathrm{r}_{\text {chr6 }}{ }^{2}$ indicates that markers in herds with higher $\mathrm{r}_{\text {chr6 }}{ }^{2}$ capture QTL in this region of the genome. This is in line with previous findings (Khatkar et al., 2004), pointing out that this segment on chromosome 6 significantly contributed to milk production traits. Obvious reactions of genetic variances for MY and fat\% on LD characteristics might be due to selection. Strong selection intensities on the cow-sire
Table 4. Correlations among continuous herd descriptors ${ }^{1}$

\begin{tabular}{lcrrrrr}
\hline & \multicolumn{5}{c}{ Herd descriptor } \\
\cline { 2 - 7 } Item & $\mathrm{r}_{\text {chr14 }}{ }^{2}$ & \multicolumn{1}{c}{$p$} & $F$ & Sire\% & \multicolumn{1}{c}{ HS } & NRR56 \\
\hline $\mathrm{r}_{\text {chr6 }}{ }^{2}$ & 0.41 & -0.06 & 0.25 & 0.12 & -0.12 & -0.14 \\
$\mathrm{r}_{\text {chr14 }}{ }^{2}$ & & 0.28 & 0.47 & -0.16 & 0.07 & -0.17 \\
$p$ & & & -0.11 & 0.13 & 0.06 & -0.01 \\
$F$ & & & & -0.24 & 0.13 & -0.27 \\
Sire\% & & & & & 0.18 & -0.05 \\
HS & & & & & & -0.08 \\
\hline
\end{tabular}

${ }^{1} \mathrm{r}_{\mathrm{chr} 6}{ }^{2}=\mathrm{r}^{2}$ on chromosome 6 between 40 and $60 \mathrm{Mbp} ; \mathrm{r}_{\mathrm{chr} 14}{ }^{2}=\mathrm{r}^{2}$ on chromosome 14 between 0 and $40 \mathrm{Mbp} ; p=$ allele frequency of the SNP located in the DGAT1 gene; $F=$ pedigree-based inbreeding coefficient; sire $\%=$ percentage of cows with a non-European Union sire; $\mathrm{HS}=$ herd size; NRR5 $6=$ nonreturn rate after $56 \mathrm{~d}$.

pathway of selection were identified for MY and fat\% in worldwide Holstein populations in the past decades (Powell et al., 2003), but cow-sire selection was less intensive for female fertility and SCC (Powell et al., 2003; Miglior et al., 2005).

Heritabilities from the MTRM (Table 5) for test-day traits in the $3 \mathrm{r}_{\text {chr6 }}{ }^{2}$ herd classes, small, middle, and high, confirmed the results from the RRM (i.e., larger heritabilities for MY and fat\% within high compared with small or middle). For SCS (in analogy to the RRM results), we found lowest heritabilities in the high intraherd $\mathrm{r}_{\text {chr6 }}{ }^{2}$ class. However, heritability differences in the different classes were minor, representing the range of standard errors.

Genetic correlations in same test-day traits were close to 1 for neighboring intra-herd $\mathrm{r}_{\text {chr6 }}{ }^{2}$ values, but decreased with increasing $\mathrm{r}_{\text {chr6 }}{ }^{2}$ distances (Figure 1B). This was especially the case for MY, but also for SCS. With regard to MY and SCS, genetic correlations between the lowest and the highest $\mathrm{r}_{\text {chr6 }}{ }^{2}$ herd were 0.35 for both traits. Genetic correlations lower than 0.80 indicate $\mathrm{G} \times \mathrm{E}$ (Robertson, 1959), and a re-ranking of animals when performing in the different genomic herd environments. Also for the MTRM (Table 5), genetic correlations were larger when correlating same traits in small and middle or in middle and high, compared with the more distant herd classes small and high. Because of the relevance of this chromosome 6 segment on milk volume, such effects were assumed for MY, but not for SCS. One argument addresses the general sensitivity of SCS (sensitivity in terms of altering genetic covariances and genetic correlations) in $\mathrm{G} \times \mathrm{E}$ studies. Using classical environmental categories (e.g., geographical regions, sea level, or organic versus conventional), genetic correlations were always close to 1 for test-day production traits, but declined for SCS. This was the case for Holstein (Nauta et al., 2006) as well as for local 


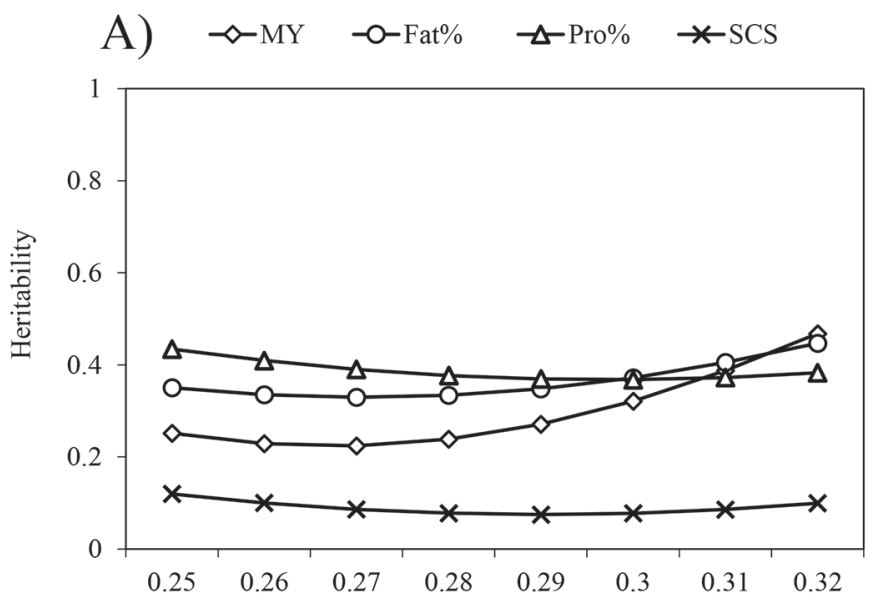

B)

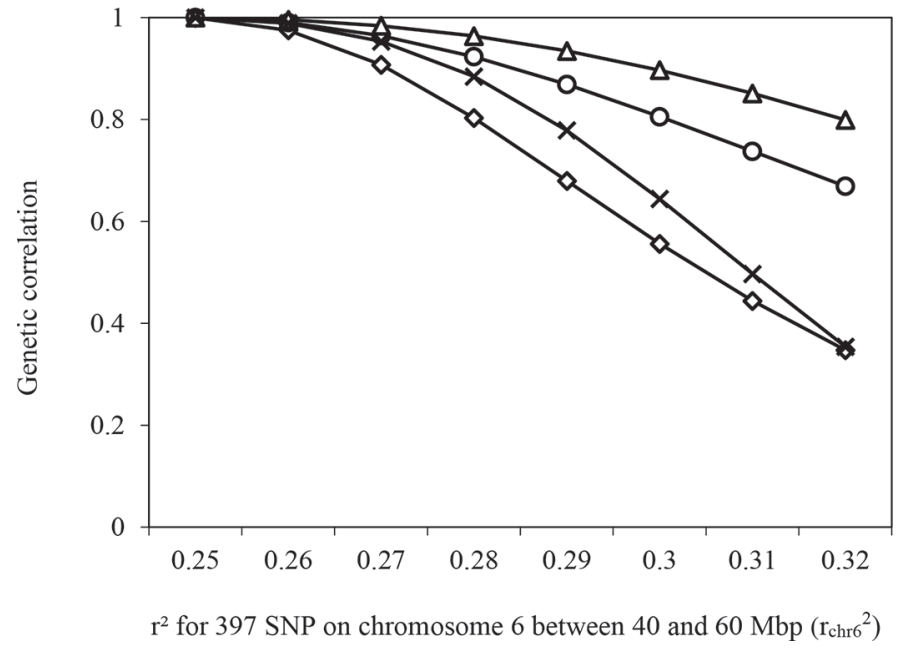

Figure 1. Heritabilities (A) and genetic correlations between the minimal level and remaining levels (B) for the genomic herd descriptor "linkage disequilibrium of $397 \mathrm{SNP}$ within 40 to $60 \mathrm{Mbp}$ on chromosome $6\left(\mathrm{r}_{\text {chr6 }}{ }^{2}\right)$ and the rest of levels" considering the following testday traits: milk yield (MY), fat percentage (fat\%), protein percentage (Pro\%), and SCS. Standard errors for heritabilities ranged from 0.053 to 0.112 for MY, from 0.076 to 0.113 for fat $\%$, from 0.085 to 0.101 for Pro\%, and from 0.020 to 0.041 for SCS. Standard errors for genetic correlations ranged from 0.001 to 0.062 for MY, from 0.001 to 0.066 for fat\%, from 0.001 to 0.073 for Pro\%, and from 0.001 to 0.098 for SCS; $\mathrm{SE}$ for genetic correlations increased with increasing distance between herd descriptors.

dual-purpose cows (Jaeger et al., 2016). Environmental sensitivity findings for SCS need ongoing investigations.

Considering the extreme 5\% tails of herds according to $\mathrm{r}_{\text {chr6 }}{ }^{2}$, rank correlations between sire EBV were larger for Pro\% and fat\% compared with MY and SCS (Table 6 ). Hence, for genetic improvements of Pro $\%$ and fat $\%$, same sires are suggested for low and high LD herds. In contrast, for MY and SCS with EBV correlations close

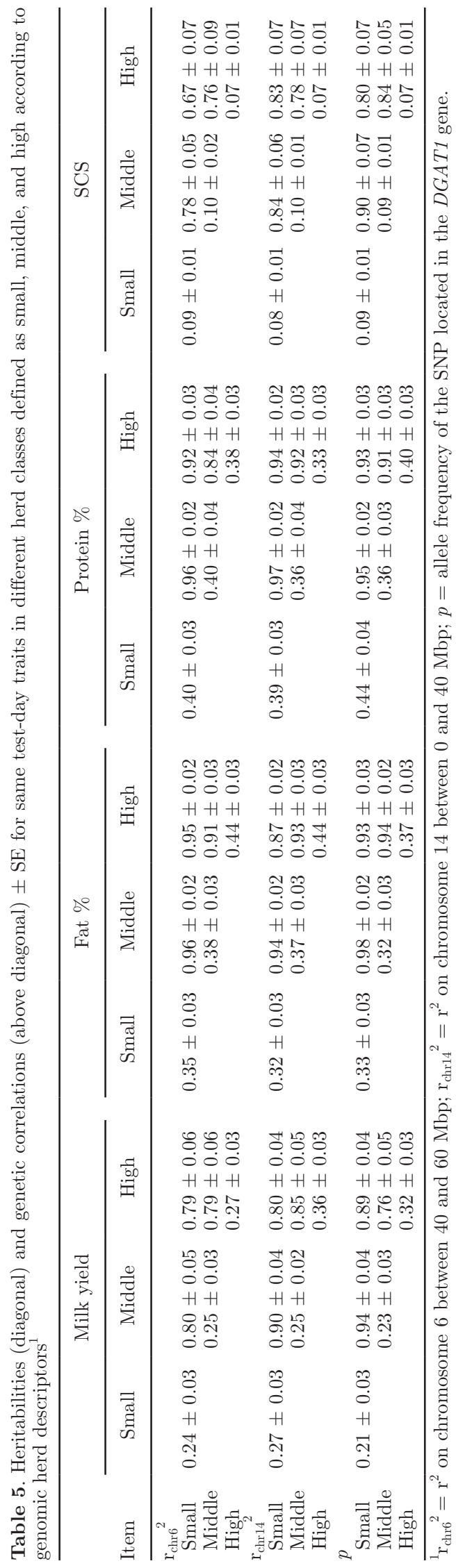

Journal of Dairy Science Vol. 101 No. 3, 2018 
Table 6. Rank correlations for estimated sire test-day trait breeding values (the 681 sires with daughters) between the lower 5 th and upper 95th percentiles for herd descriptors

\begin{tabular}{lcccc}
\hline & \multicolumn{3}{c}{ Test-day trait } \\
\cline { 2 - 5 } Herd descriptor & Milk yield & Fat \% & Protein \% & \multirow{2}{*}{ SCS } \\
\hline $\mathrm{r}^{2}$ on chromosome 6 between 40 and 60 Mbp $\left(\mathrm{r}_{\text {chr6 }}{ }^{2}\right)$ & 0.80 & 0.96 & 0.99 & 0.84 \\
$\mathrm{r}^{2}$ on chromosome 14 between 0 and 40 Mbp $\left(\mathrm{r}_{\text {chr14 }}\right)$ & 0.78 & 0.94 & 1.00 & 0.88 \\
Allele frequency of the SNP located in the DGAT1 gene $(p)$ & 0.83 & 0.92 & 0.95 & 0.87 \\
Pedigree based inbreeding coefficient $(F)$ & 0.73 & 0.92 & 0.97 & 0.92 \\
Percentage of cows with a non-European Union sire (sire\%) & 0.58 & 0.99 & 0.95 & 0.80 \\
Herd size (HS) & 0.80 & 0.95 & 0.97 & 0.61 \\
Nonreturn rate after 56 d (NRR56) & 0.82 & 0.93 & 0.93 & 0.69 \\
\hline
\end{tabular}

to 0.80 , specific sires should be selected for specific genomic herd architectures.

With regard to heritabilities for test-day traits on the continuous to $\mathrm{r}_{\text {chr14 }}^{2}$ scale (Figure 2A), again we identified lowest values in a narrow range $(0.11-0.13)$ for SCS. In analogy with the $\mathrm{r}_{\text {chr6 }}{ }^{2}$ descriptor, heritabilities for MY and fat\% gradually increased with increasing levels for $\mathrm{r}_{\text {chr14 }}{ }^{2}$. Among all test-day traits, the highest heritability of 0.53 for fat $\%$ was observed at the highest $\mathrm{r}_{\mathrm{chr} 14}{ }^{2}$ level. The increase of heritabilities for MY and fat $\%$ with increasing intra-herd $\mathrm{r}_{\text {chr14 }}{ }^{2}$, and also the larger extent of LD for the chromosome 14 segment compared with the segment on chromosome 6 , might be due to the pronounced effect of the DGAT1 gene. The segment from $1,463,676$ to $2,117,455$ bp on chromosome 14 explained $41.4 \%$ of the total SNP variance for fat\% (van Binsbergen et al., 2012), reflecting the variance proportion (31\%) directly explained by the DGAT1 K232A polymorphism (Grisart et al., 2002). Heritabilities for Pro\% slightly decreased with increasing intraherd $\mathrm{r}_{\mathrm{chr} 14}{ }^{2}$. In Holstein populations, allele substitution effects for the DGAT1 K232A polymorphism on Pro\% were quite small, in the range from $0.05 \%$ (Kühn et al., 2004) to $0.08 \%$ (Thaller et al., 2003). With regard to the MTRM, heritabilities for MY and fat\% were also largest in the herd class high (Table 5). Also the slight heritability decrease for Pro\% from small to high, and the quite constant SCS heritabilities for all 3 herd classes, confirmed RRM estimates.

For the RRM applications (Figure 2B), genetic correlations of 0.63 for fat $\%$, of 0.67 for SCS, and of 0.37 for MY, were quite small between the minimum and maximum $\mathrm{r}_{\mathrm{chr} 14}{ }^{2}$ levels, suggesting a gradually changing genetic background of the 3 test-day traits in dependency of $\mathrm{r}_{\text {chr14 }}$. In general, with RRM and time dependent covariates, estimates at the "extreme ends of the time scale" differed from the remaining scale levels and were associated with large standard errors (Gernand and König, 2014). However, in the present study for the $\mathrm{r}_{\text {chr14 }}{ }^{2}$ descriptor, standard errors of genetic correla- tions for fat\%, Pro\%, and MY were generally smaller than 0.07 . For Pro\%, not only did the heritability curve differ from the corresponding estimates for fat $\%$ and MY (Figure 2A), but also the genetic correlations between different $\mathrm{r}_{\text {chr14 }}{ }^{2}$ levels were substantially larger (Figure 2B). With regard to genetic correlations from the MTRM (Table 5), and with regard to correlations between sire EBV (Table 6), estimates confirmed the general trends from the RRM, but were substantially larger for all traits (closer to 1) and exactly 1.00 for Pro\% (EBV correlations).

Heritability pattern for test-day traits on the continuous allele frequency $(p)$ scale (Figure 3a) are in close agreement with the corresponding trait curves on the $\mathrm{r}_{\text {chr14 }}{ }^{2}$ scale. This is the logical consequence, because we assume the effect of DGAT1 selection strategies on $\mathrm{r}_{\mathrm{chr} 14}{ }^{2}$, as indicated via the moderate correlation of 0.28 between both herd descriptors. Again, heritabilities for SCS were quite constant in the range from 0.09 to 0.11 for all intra-herd allele frequencies, and heritabilities for MY and fat\% increased with increasing $p$. In the present study, the minor allele frequency for the SNP marker ARS-BFGL-NGS-4939 averaged across all herds was 0.31 , and therefore larger than in Italian Holsteins (Minozzi et al., 2013). The larger minor allele frequency indicate more diverse selection strategies in German herds: some farms focus on genetic improvements of MY, whereas other farm have a stronger focus on the content trait fat $\%$. Hence, genetic parameters of both traits MY and fat\% altered on the continuous $p$ scale. Significant effects of minor allele frequencies for the marker ARS-BFGL-NGS-4939 on allele substitution effects for production traits were identified in Italian (Minozzi et al., 2013) and in Chinese Holstein cattle populations (Jiang et al., 2010). In consequence, allele frequencies affect genetic variances. Heritabilities from the MTRM for fat\% and MY were larger in the high classes compared with the small classes, but we detected only minor differences between small and middle (Table 5). Again, and in agreement with the 


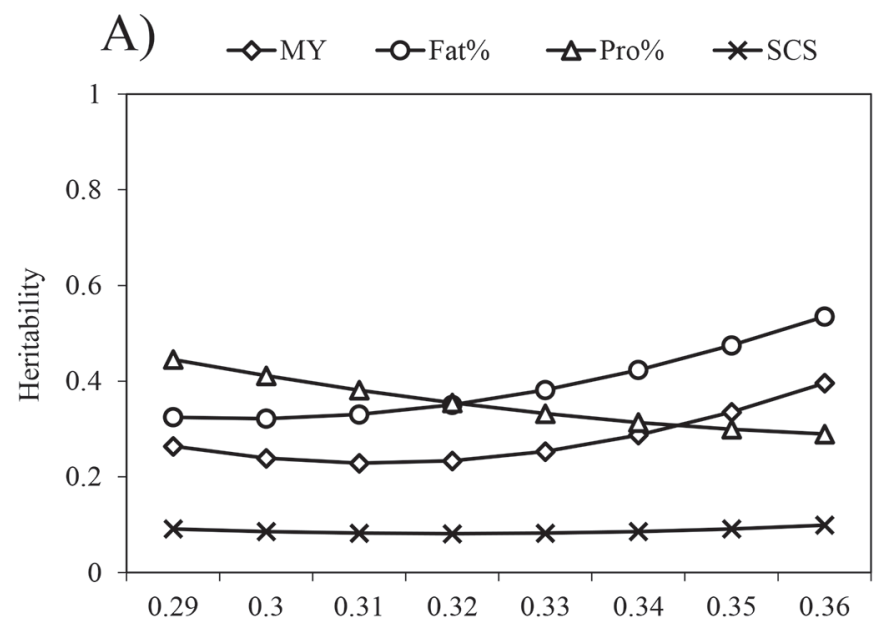

B)

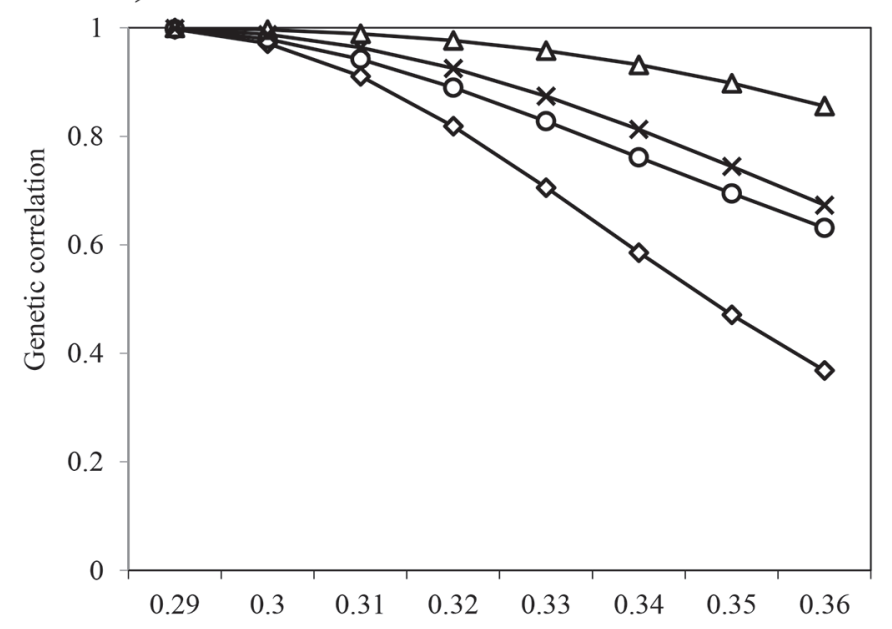

$\mathrm{r}^{2}$ for $786 \mathrm{SNP}$ on chromosome 14 between 0 and $40 \mathrm{Mbp}\left(\mathrm{r}_{\mathrm{chr} 14^{2}}\right)$

Figure 2. Heritabilities (A) and genetic correlations between the minimal level and remaining levels (B) for the genomic herd descriptor "linkage disequilibrium of $786 \mathrm{SNP}$ between 0 and $40 \mathrm{Mbp}$ on chromosome $14\left(\mathrm{r}_{\text {chr1 } 14}{ }^{2}\right)$ " considering the following test-day traits: milk yield (MY), fat percentage (fat\%), protein percentage (Pro\%), and SCS. Standard errors for heritabilities ranged from 0.054 to 0.110 for MY, from 0.074 to 0.113 for fat\%, from 0.078 to 0.100 for Pro\%, and from 0.021 to 0.041 for SCS. Standard errors for genetic correlations ranged from 0.001 to 0.059 for MY, from 0.001 to 0.063 for fat $\%$, from 0.001 to 0.079 for Pro\%, and from 0.001 to 0.065 for SCS; SE for genetic correlations increased with increasing distance between herd descriptors.

RRM estimates, heritabilities for Pro\% and SCS were quite constant for the 3 herd classes (Table 5).

The shape of genetic correlation curves (Figure 3B) was identical for all test-day traits. Genetic correlations were minimal when correlating the respective traits from intra-herd allele frequencies in greatest distance (i.e., traits recorded at $P=0.6$ and at $P=0.825$ ). However, genetic correlations for the $p$ descriptor were
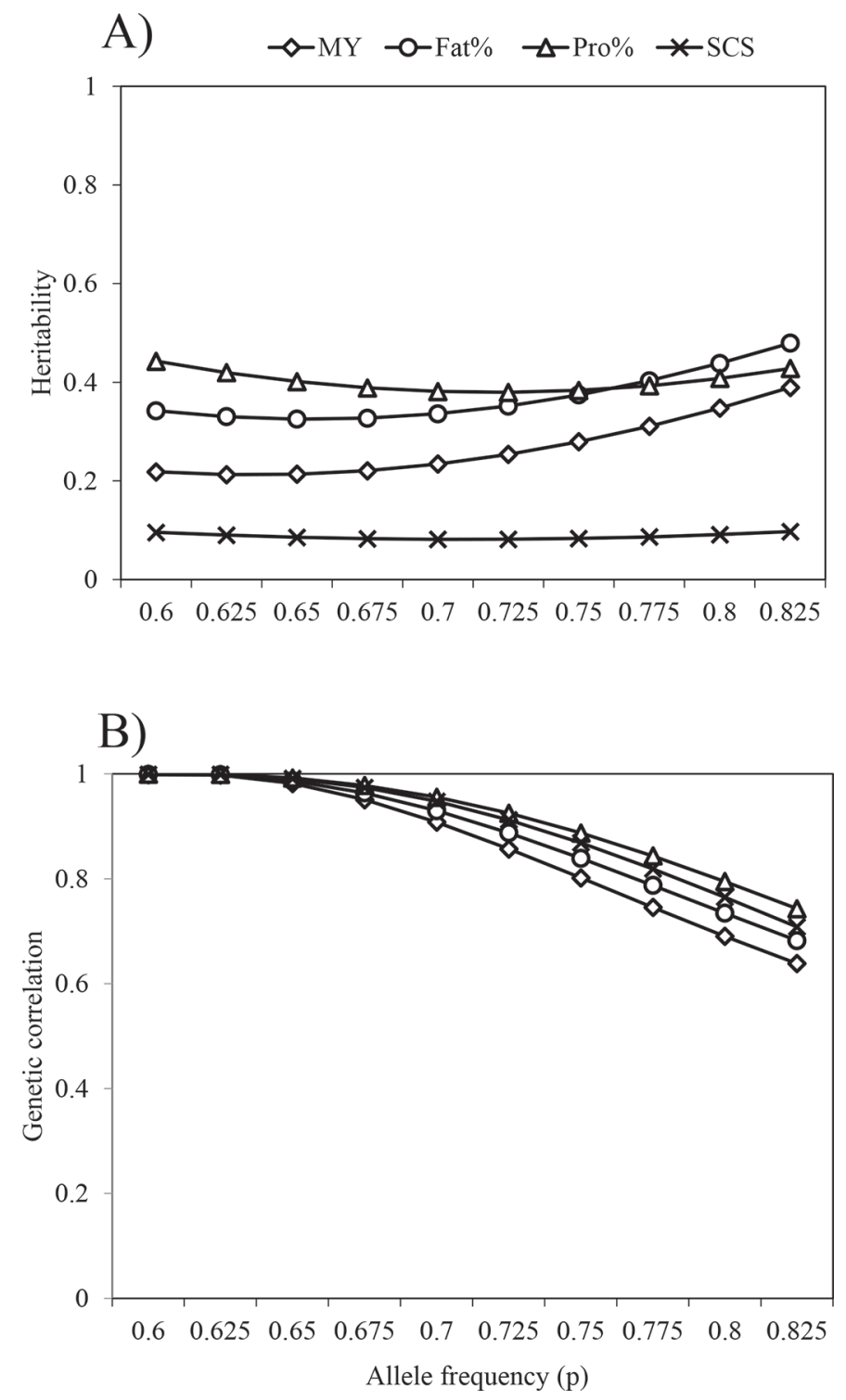

Figure 3. Heritabilities (A) and genetic correlations between the minimal level and remaining levels (B) for the genomic herd descriptor "allele frequency of the marker ARS-BFGL-NGS-4939 (p)" considering the following test-day traits: milk yield (MY), fat percentage (fat\%), protein percentage (Pro\%), and SCS. Standard errors for heritabilities ranged from 0.047 to 0.090 for MY, from 0.070 to 0.105 for fat $\%$, from 0.080 to 0.097 for Pro\%, and from 0.020 to 0.031 for SCS. Standard errors for genetic correlations ranged from 0 to 0.063 for MY, from 0 to 0.056 for fat $\%$, from 0.001 to 0.058 for Pro\%, and from 0.001 to 0.116 for SCS; SE for genetic correlations increased with increasing distance between herd descriptors.

generally larger compared with the LD descriptors. In agreement with the $\mathrm{r}_{\text {chr14 }}{ }^{2}$ descriptor, the lowest genetic correlations were estimated for MY and the largest for Pro\%. Genetic correlations from the MTRM (Table 5) and the correlations between sire EBV (Table 6) were larger than 0.80 for all test-day traits. 
Genetic Herd Descriptors. Among all herd descriptors, we identified the largest association between $\mathrm{r}_{\text {chr1 }}{ }^{2}$ and $F$ (correlation coefficient of 0.47 ). In consequence, similarities of heritability curves were identified for both continuous herd descriptors $\mathrm{r}_{\text {chr14 }}{ }^{2}$ and $F$. Heritabilities were quite constant (0.06 to 0.10) for SCS on a low $F$ level, heritabilities decreased with increasing $F$ for Pro\%, and heritabilities for MY and fat\% increased within the range from moderate to highest intra-herd inbreeding coefficients (Figure 4a). However, also for MY and fat\%, the heritability was largest for the lowest intra-herd inbreeding coefficient. Theoretically, in a long-term perspective, intensive selection accumulates inbreeding, and reduces genetic variation within populations (Falconer and Mackay, 1996). In the present study, largest heritabilities for MY, fat\%, and Pro\% for herds with lowest inbreeding are in line with those theoretical expectations. Regarding intra-herd inbreeding coefficients in the present study, only minor herd differences existed, in a narrow range from $F=0.034$ to $F=0.052$. Increase of $F$ did not influence heritabilities for SCS, reflecting the nonsignificant inbreeding depressions for SCS on phenotypic scales in older (Miglior et al., 1992) as well as in more recent studies (Thompson et al., 2000). As found for genomic descriptors, also for pedigree-based $F$, heritability estimates from the MTRM confirmed the RRM trends, but (apart from MY) estimates in the 3 different $F$ classes only differed marginally (Table 7).

Genetic correlations in MY decreased when considering herds with large intra-herd $F$ differences (Figure 4B), supporting genetic correlation estimates from the MTRM (Table 7), and also reflecting the sire EBV correlation for MY (Table 6). Inbreeding within herds accumulated due to the strong selection focus on MY in past decades (König and Simianer, 2006), which might explain the pronounced effects of $F$ on genetic covariance and genetic correlation estimates for MY. Among all herd descriptors, only for the intra-herd inbreeding scale, genetic correlation estimates were largest for SCS, but associated with largest SE (Figure 4B). Nevertheless, genetic correlations for SCS across different herd classes were also quite large with $\mathrm{r}_{\mathrm{g}}>0.80$ (Table 7). Quantitative genetic parameters for SCS from the present analysis might be surprising because, in general, low heritability functional traits react more sensitively to environmental or herd descriptor alterations compared with production traits. Nevertheless, SCS seems to be a specific functional trait. Generally, in genomic predictions, and also when following deterministic equations (Goddard, 2009), reliabilities of genomic breeding values increased with increasing trait heritability. However, in German national genomic evaluations for Holstein sires, among all traits, prediction accuracies are largest for low heritability SCS.

In addition to intra-herd inbreeding coefficients, we estimated genetic parameters in dependency of intraherd pedigree based relationships. As expected, results were similar for both descriptors, because relationships among parents directly reflect inbreeding in offspring. Also for the intra-herd genetic relationships, genetic
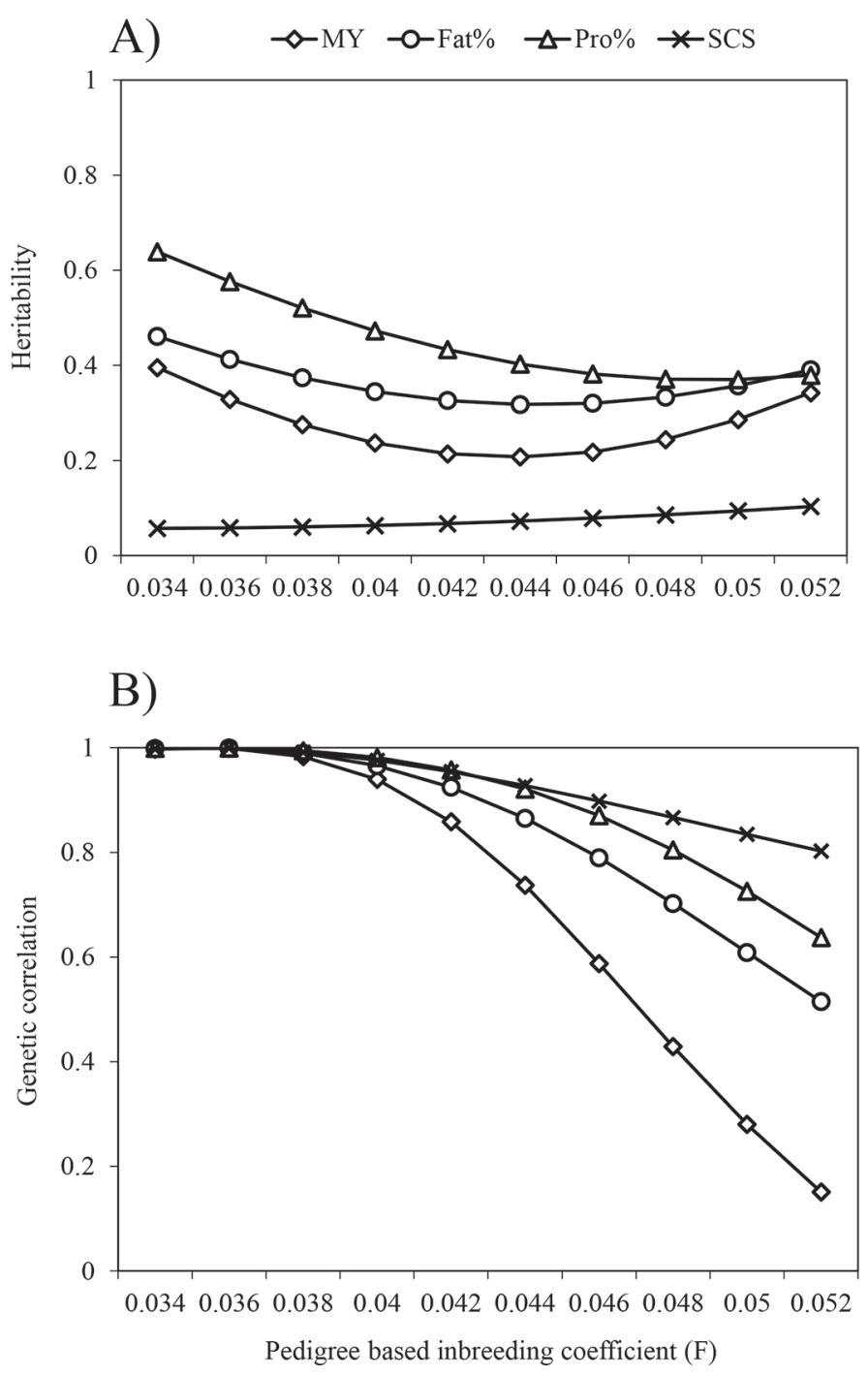

Figure 4. Heritabilities (A) and genetic correlations between the minimal level and the remaining levels (B) for the genetic herd descriptor "inbreeding coefficient $(\mathrm{F})$ " considering the following test-day traits: milk yield (MY), fat percentage (fat\%), protein percentage (Pro\%), and SCS. Standard errors for heritabilities ranged from 0.048 to 0.115 for MY, from 0.069 to 0.117 for fat\%, from 0.078 to 0.147 for Pro\%, and from 0.019 to 0.037 for SCS. Standard errors for genetic correlations ranged from 0.001 to 0.050 for MY, from 0.01 to 0.062 for fat\%, from 0.001 to 0.069 for Pro\%, and from 0.001 to 0.306 for SCS; $\mathrm{SE}$ for genetic correlations increased with increasing distance between herd descriptors. 


\begin{tabular}{|c|c|c|c|c|c|c|c|}
\hline & 焉0 & 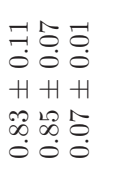 & 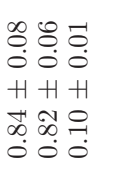 & 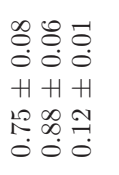 & \multicolumn{2}{|c|}{ 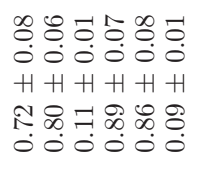 } & \\
\hline$\sum_{\mathscr{N}}^{\infty}$ & $\begin{array}{l}\stackrel{0}{\vec{Z}} \\
\stackrel{0}{*}\end{array}$ & $\begin{array}{ll}2 & -1 \\
0 & 0 \\
0 & 0 \\
H & +1 \\
+1 & 0 \\
0 & 0 \\
0 & 0\end{array}$ & $\begin{array}{ll}1 & 0 \\
0 & 0 \\
0 & 0 \\
0 & 0 \\
H & H \\
1 & 1 \\
0 & 0 \\
0 & 0 \\
0 & 0\end{array}$ & $\begin{array}{ll}8 & 1 \\
0 & 0 \\
0 & 0 \\
H & +1 \\
\infty & 0 \\
\infty & 0 \\
0 & 0\end{array}$ & $\begin{array}{ll}2 & 0 \\
0 & 0 \\
0 & 0 \\
H & +1 \\
0 & 0 \\
0 & 0 \\
0 & 0\end{array}$ & 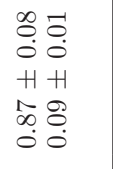 & $\begin{array}{l}-1 \\
0 \\
0\end{array}$ \\
\hline & 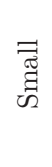 & $\begin{array}{l}\overrightarrow{1} \\
0 \\
0 \\
+1 \\
\infty \\
0 \\
0\end{array}$ & $\begin{array}{l}\text { Tे } \\
0 \\
0 \\
+1 \\
0 \\
0 \\
0\end{array}$ & 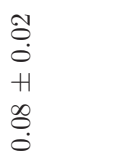 & $\begin{array}{l}\overrightarrow{0} \\
0 \\
0 \\
H \\
1 \\
0 \\
0 \\
0\end{array}$ & $\begin{array}{l}-0 \\
0 \\
0 \\
H \\
0 \\
0 \\
0\end{array}$ & 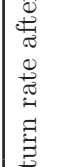 \\
\hline & $\frac{97}{\infty 00}$ & 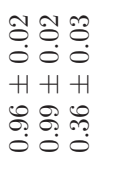 & 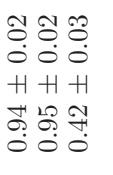 & 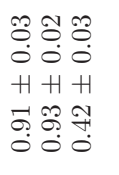 & 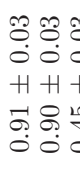 & 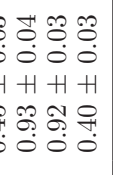 & $\begin{array}{l}0 \\
a \\
\| 1 \\
0 \\
11 \\
12 \\
01\end{array}$ \\
\hline 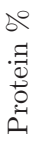 & $\underset{ت}{\stackrel{\Xi}{*}}$ & 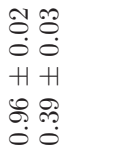 & 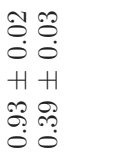 & 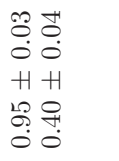 & 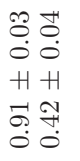 & 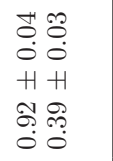 & 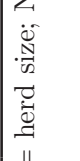 \\
\hline & $\begin{array}{l}\text { न्चี } \\
\text { भี }\end{array}$ & $\begin{array}{l}\mathscr{O} \\
0 \\
+ \\
H \\
\vec{H} \\
\dot{0}\end{array}$ & 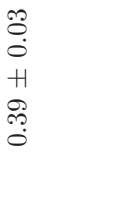 & 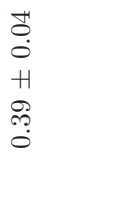 & $\begin{array}{l}\dddot{0} \\
0 \\
+ \\
+ \\
\infty \\
\dddot{0}\end{array}$ & $\begin{array}{l}\approx \\
0 \\
0 \\
H \\
0 \\
0+1 \\
0\end{array}$ & 些 \\
\hline & $\begin{array}{l}\frac{9}{60} \\
: 7\end{array}$ & 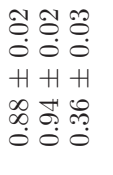 & 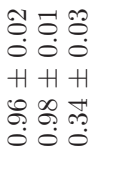 & 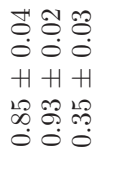 & 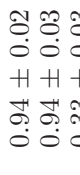 & 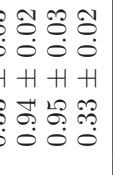 & $\mid \begin{array}{c}0 \\
0 \\
0 \\
\vdots \\
0 \\
1 \\
0\end{array}$ \\
\hline 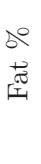 & $\underset{ت}{\stackrel{\Xi}{ت}}$ & 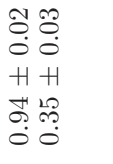 & $\begin{array}{ll}2 & 0 \\
0 & 0 \\
0 & 0 \\
H & 0 \\
H & H \\
5 & 10 \\
0 & 0 \\
0 & 0\end{array}$ & 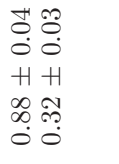 & 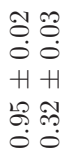 & 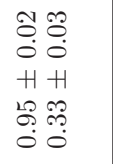 & 吾 \\
\hline & 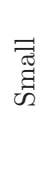 & $\begin{array}{l}\because 0 \\
0 \\
0 \\
H \\
F \\
\dot{F}\end{array}$ & $\begin{array}{l}\mathscr{O} \\
\dot{0} \\
H \\
1 \\
20 \\
0 \\
0\end{array}$ & $\begin{array}{l}\dot{H} \\
\dot{0} \\
H \\
H \\
10 \\
0 \\
0\end{array}$ & $\begin{array}{l}\mathscr{O} \\
0 \\
+1 \\
H \\
20 \\
ٌ \\
0\end{array}$ & $\begin{array}{l}\stackrel{\vartheta}{0} \\
\dot{0} \\
H \\
\vec{H} \\
\ddot{0}\end{array}$ & 递 \\
\hline & 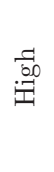 & 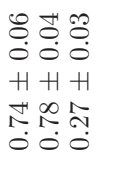 & 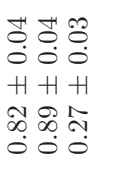 & 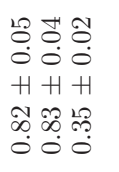 & 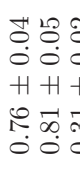 & 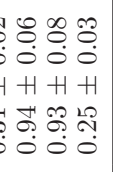 & 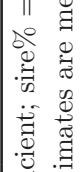 \\
\hline 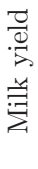 & 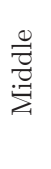 & 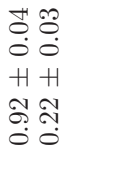 & 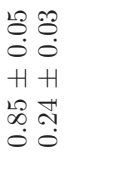 & 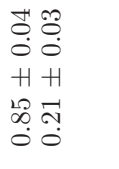 & 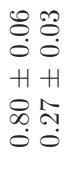 & 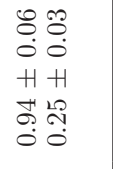 & \begin{tabular}{l}
0 \\
0 \\
$\infty$ \\
$:$ \\
\hdashline \\
0 \\
0 \\
0 \\
0
\end{tabular} \\
\hline & 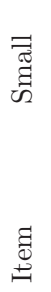 & 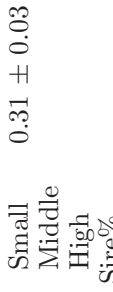 & 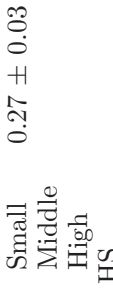 & 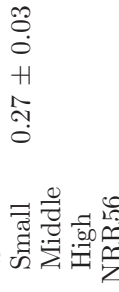 & 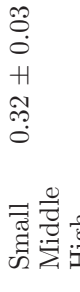 & $\begin{array}{l}\because \\
0 \\
0 \\
+1 \\
0 \\
0 \\
0 \\
0\end{array}$ & 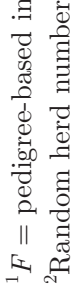 \\
\hline
\end{tabular}

correlation were largest for SCS, with $\mathrm{r}_{\mathrm{g}}>0.92$ for all pairwise combinations from the RRM application. In agreement with the intra-herd inbreeding coefficients, genetic correlations for MY substantially decreased with increasing intra-herd relationship differences. For example, the genetic correlation was only 0.10 when correlating MY between herds with the lowest intraherd relationship coefficient (0.09) and herds with the largest intra-herd relationship coefficient (0.14).

For the sire\% herd descriptor, heritability curves were different for fat\% and Pro\% (Figure 5A). Heritabilities for fat\% slightly decreased from 0.38 to 0.25 with the increase of intra-herd sire \%, but heritabilities for Pro\% increased from 0.39 to 0.52 . Only by trend, the MTRM heritabilities for distinct classes (Table 7) reflect the RRM heritability curve pattern for fat $\%$ and Pro\%. Also for this herd descriptor, heritabilities for SCS were in a low and constant range over all sire\% levels.

Especially genetic correlations for MY were extremely low for substantial differences in sire herd structures (Figure 5B). The genetic correlation in MY between the $0 \%$ of non-EU sires herds with the $39 \%$ of nonEU sires was only 0.26. Such an effect of the genetic structure of herds on genetic correlations reflects the findings from our previous studies as explained via Table 1. The genetic composition of herds influenced genetic correlations in yield traits, and it was not only the herd location (east versus west), which contributed to $\mathrm{G} \times \mathrm{E}$. Sires from the United States used in German AI programs were intensively selected elite sires with mostly outstanding genetic values for MY and protein yield. In contrast, sires from German origin also represented young bulls from progeny testing programs with partly extremely low EBV, or proven cow sires with only average genetic values. In the era of genomic selection allowing intensive pre-selection among young sires, genetic levels of all sire origins substantially improved. Hence, in future analyses in this regard, we hypothesize only minor effects of sire herd structures on genetic covariance component estimates.

Obvious decreases in genetic correlation estimates with increasing herd distances for sire\% were identified for MY and for SCS (Figure 5B). The MY and SCS genetic correlation decrease is in line with results for sire breeding value correlations (Table 6), and with estimates from the MTRM (Table 7). As outlined above, $\mathrm{G} \times \mathrm{E}$ for SCS were always obvious in previous studies when grouping herds according to classical environmental or farm management descriptors (Hayes et al., 2003; Mulder et al., 2004; van Binsbergen et al., 2012). Generally, such dairy cattle farms applying an improved herd management have a stronger focus on proven sires from foreign countries with outstanding genetic values (König and Simianer, 2006). 
Phenotypic Herd Descriptors. Increasing herd size was associated with a SCS heritability increase (Figure 6A). Hammond (1947) suggested superior environments for animal selection, because in superior environments, animals can fully express their true genetic potential. Henderson (1964) recommended optimal environments in terms of herd husbandry and manage-
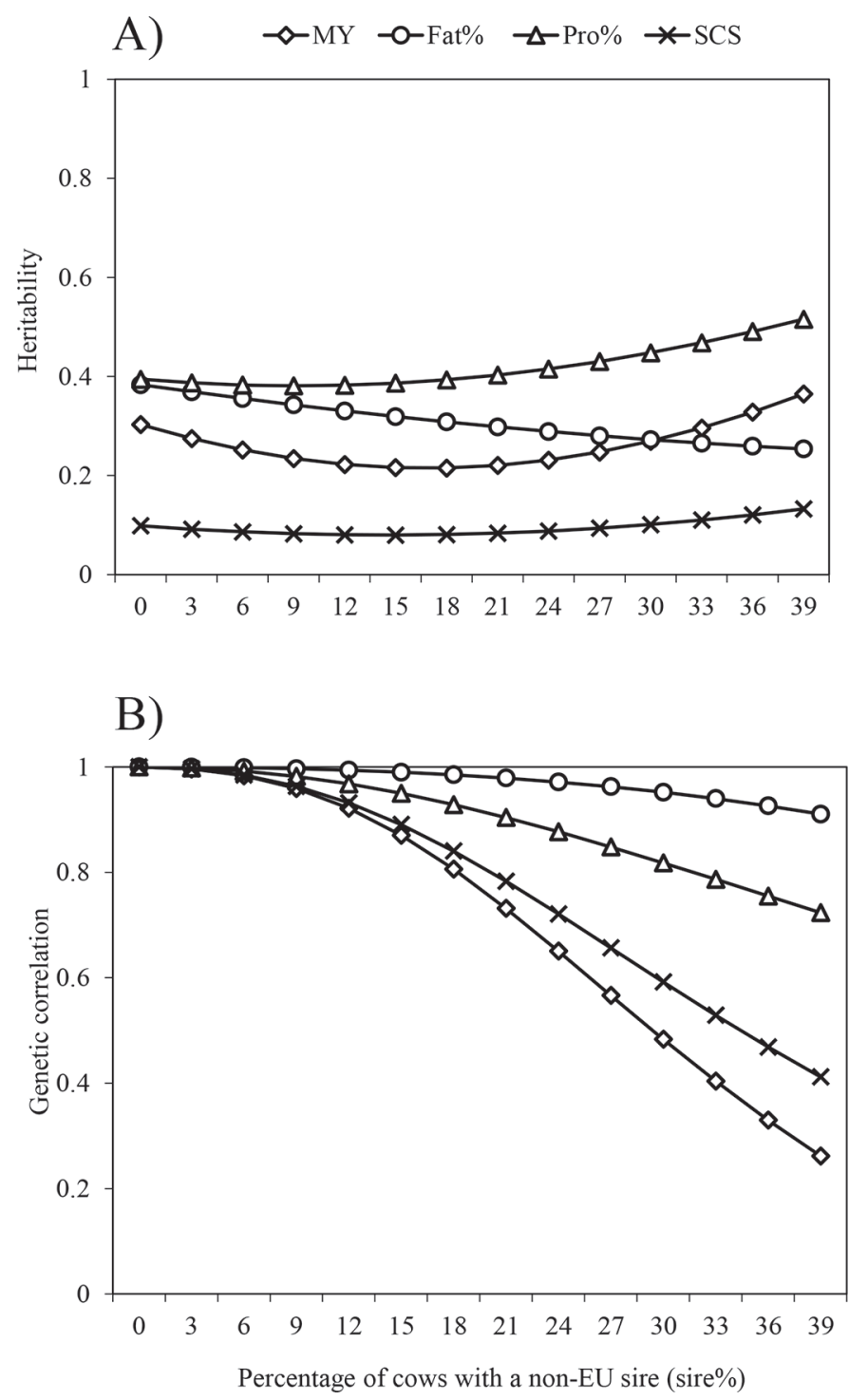

Figure 5. Heritabilities (A) and genetic correlations between the minimal level and remaining levels for the genetic herd descriptor "percentage of cows with a non-EU sire (sire\%)" (B) considering the following test-day traits: milk yield (MY), fat percentage (fat\%), protein percentage (Pro\%), and SCS. Standard errors for heritabilities ranged from 0.042 to 0.083 for MY, from 0.055 to 0.070 for fat $\%$, from 0.070 to 0.102 for Pro\%, and from 0.017 to 0.040 for SCS. Standard errors for genetic correlations ranged from 0.001 to 0.048 for MY, from 0.001 to 0.054 for fat\%, from 0.001 to 0.051 for Pro\%, and from 0.001 to 0.075 for SCS; SE for genetic correlations increased with increasing distance between herd descriptors. ment conditions for progeny testing in AI programs. König et al. (2005) identified improved intra-herd feeding, husbandry, and management conditions in largescale farms. Hence, a large German dairy cattle farm might represent such a superior environment, allowing clear genetic differentiation. However, regarding genetic differentiation in functional health or health indicator traits (e.g., SCS), Schierenbeck et al. (2011) found extreme daughter yield deviations, larger heritabilities, and larger additive-genetic variances in herds where the cows' immune system is under challenge. Larger heritabilities for MY in large-scale herds (Figure 6A, Table 7) correspond with previous findings in other German federal states for protein yield (König et al., 2005).

Genetic correlations from the RRM between the smallest and the largest herd were quite low for MY (0.27), and even lower for SCS (0.16) (Figure 6B). Accordingly, genetic correlations in both traits between the distant herd classes small and high were larger compared with the more similar herd classes small and middle, or middle and high (Table 7). However, substantially lower genetic correlations for MY and SCS from the RRM compared with the MTRM needs further clarification. Partly surprising or overestimated genetic (co)variance components were identified in previous RRM studies when using continuous time scales (Gernand and König, 2014). Explanations addressed the limited number of observations at the extreme ends of the time scale, or the covariance function used for longitudinal data analyses. Due to the substantial differences in German farm types (i.e., on one hand the small family farm and on the other hand large-scale industrial types), data stratification according to herd sized contributed to $\mathrm{G} \times \mathrm{E}$. In contrast, in other countries, such as Australia (Hayes et al., 2003), genetic correlations were close to 1 when grouping herds according to herd size.

Remaining test-day production trait heritabilities continuously increased from the middle of the NRR56 scale (NRR56 $=0.50)$ toward best fertility herds $(\mathrm{NRR} 56=0.69)$. A high fertility status of herds reflects improved farm management, contributing to optimized genetic differentiation (Schierenbeck et al., 2011). For MY and fat\%, heritabilities were quite large in herds with extremely poor nonreturn rates (Figure 7A). This was also the case for the MTRM applications (Table 7). Some authors (e.g., König et al., 2008) were very critical of the trait nonreturn rate, because biased genetic (co)variance components might be due to poor data quality (e.g., the utilization of natural service bulls or insufficient trait recording).

The shape of genetic correlation curves, and genetic correlations between the worst NRR56 herd with re- 
maining herds, were quite similar for all test-day traits (Figure 7B). Lowest genetic correlations were found for SCS, and were largest for fat\% and Pro\%. In studies aiming on phenotypic herd descriptors (Jaeger et al., 2016), low heritability functional traits were more susceptible to $\mathrm{G} \times \mathrm{E}$ compared with high heritability

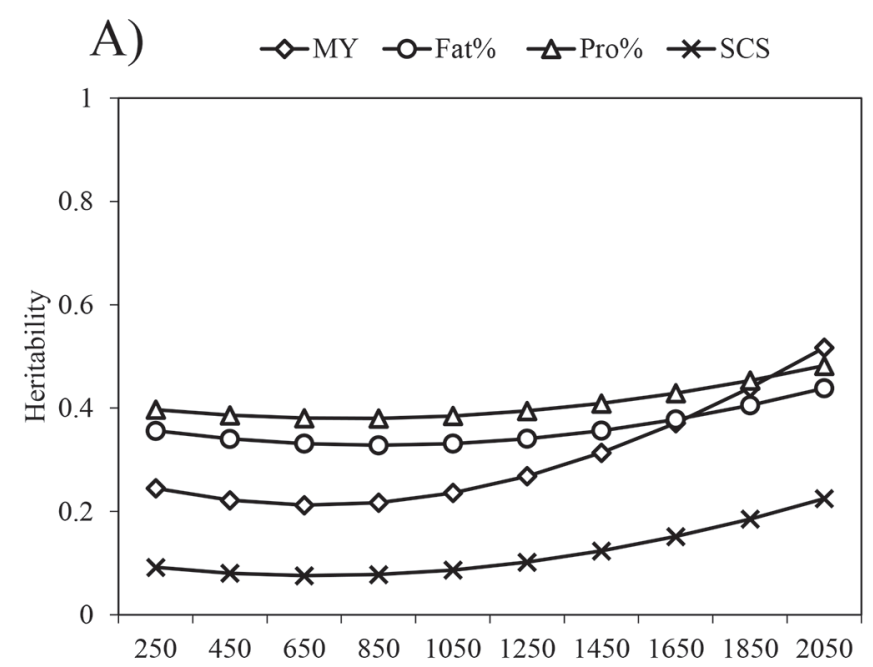

B)

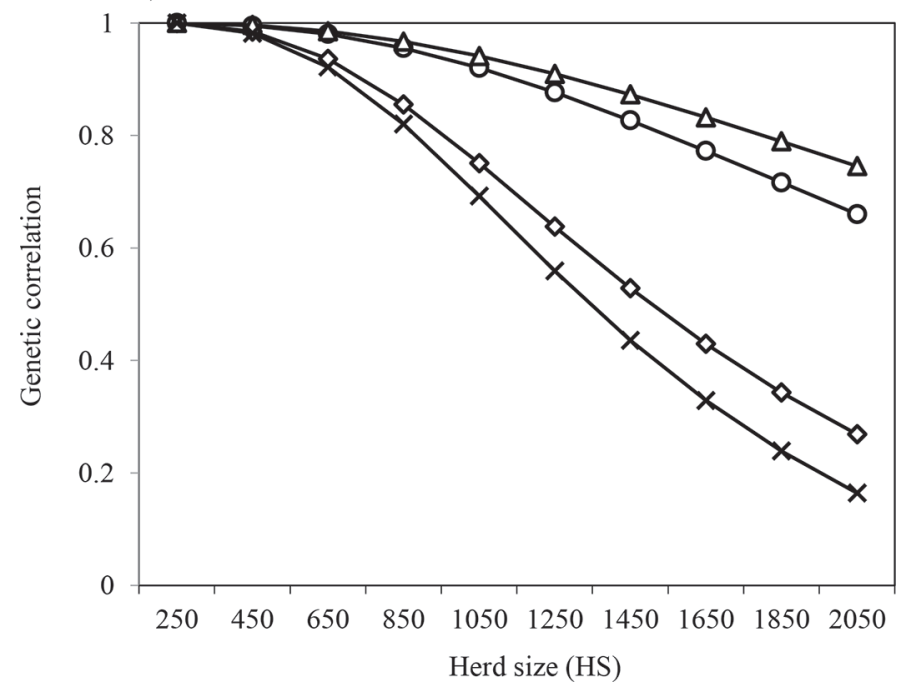

Figure 6. Heritabilities (A) and genetic correlations between the minimal level and remaining levels for the phenotypic herd descriptor "herd size (HS)" (B) considering the following test-day traits: milk yield (MY), fat percentage (fat\%), protein percentage (Pro\%), and SCS. Standard errors for heritabilities ranged from 0.047 to 0.111 for MY, from 0.069 to 0.097 for fat\%, from 0.079 to 0.105 for Pro\%, and from 0.019 to 0.057 for SCS. Standard errors for genetic correlations ranged from 0.001 to 0.039 for MY, from 0.001 to 0.048 for fat $\%$, from 0.001 to 0.046 for Pro\%, and from 0.001 to 0.048 for SCS; SE for genetic correlations increased with increasing distance between herd descriptors. production traits. Accordingly, correlations among sire EBV reflect obvious environmental sensitivity for SCS and MY (Table 7).

For the random herd descriptor and the MTRM application, genetic correlations in same traits from different random herd classes were larger than 0.90 for
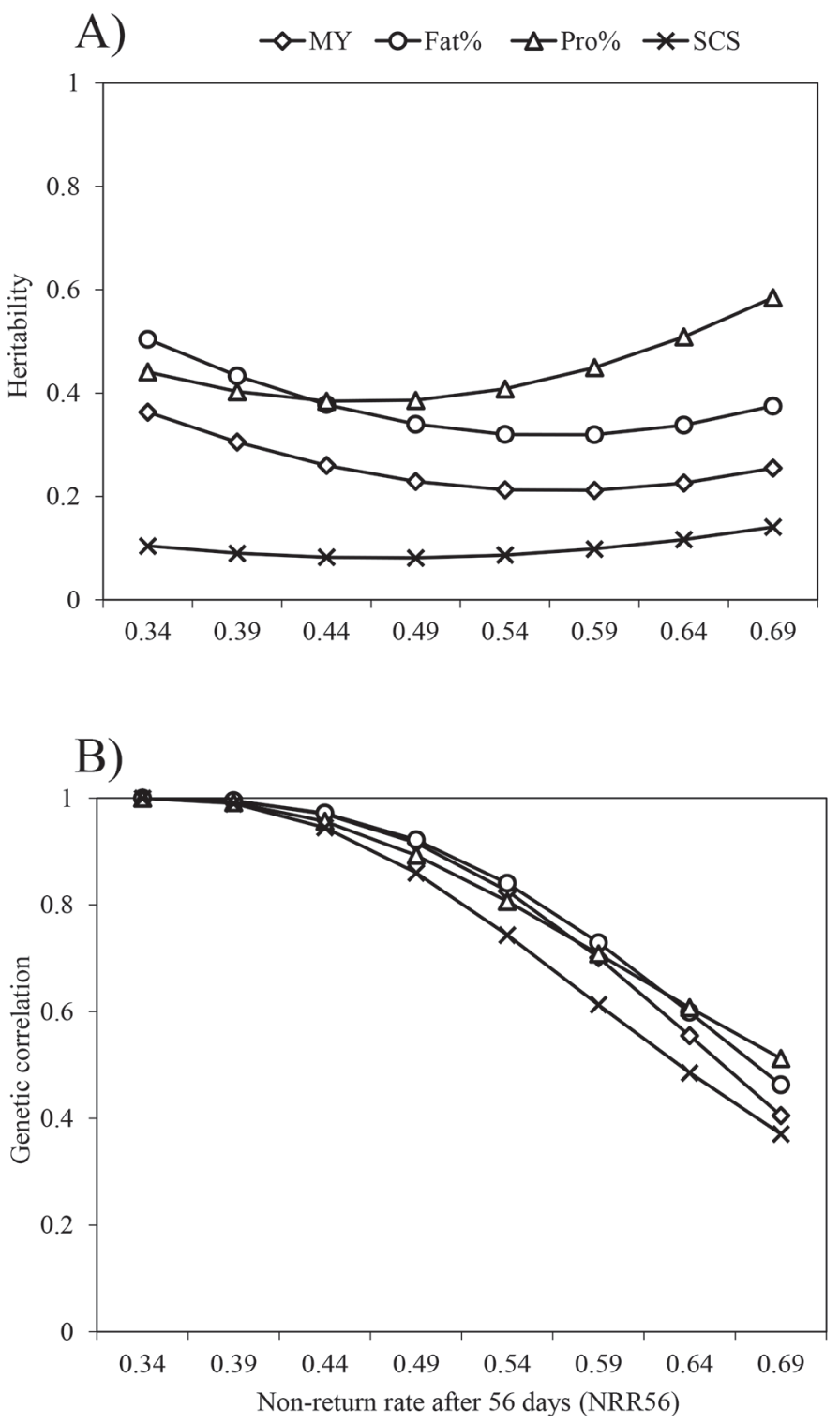

Figure 7. Heritabilities (A) and genetic correlations between the minimal level and remaining levels for the phenotypic herd descriptor "nonreturn rate after 56 days (NRR56)" (B) considering the following test-day traits: milk yield (MY), fat percentage (fat\%), protein percentage (Pro\%), and SCS. Standard errors for heritabilities ranged from 0.051 to 0.088 for MY, from 0.075 to 0.117 for fat\%, from 0.089 to 0.137 for Pro\%, and from 0.021 to 0.045 for SCS. Standard errors for genetic correlations ranged from 0.001 to 0.048 for MY, from 0.001 to 0.046 for fat\%, and from 0.001 to 0.083 for SCS; SE for genetic correlations increased with increasing distance between herd descriptors. 
Table 8. Akaike information criteria (AIC) and Schwarz Bayesian information criteria (BIC) for random regression models with different continuous herd descriptors ${ }^{1}$

\begin{tabular}{|c|c|c|c|c|c|c|c|c|}
\hline \multirow[b]{2}{*}{ Descriptor } & \multicolumn{2}{|c|}{ Milk yield } & \multicolumn{2}{|c|}{ Fat $\%$} & \multicolumn{2}{|c|}{ Protein \% } & \multicolumn{2}{|c|}{ SCS } \\
\hline & $\mathrm{AIC}$ & $\mathrm{BIC}$ & $\mathrm{AIC}$ & $\mathrm{BIC}$ & $\mathrm{AIC}$ & $\mathrm{BIC}$ & $\mathrm{AIC}$ & $\mathrm{BIC}$ \\
\hline $\mathrm{r}_{\text {chrl14 }}{ }^{2}$ & 986,371 & 986,423 & $-102,382$ & $-102,330$ & $-582,198$ & $-582,146$ & 395,163 & 395,216 \\
\hline$p$ & 986,377 & 986,423 & $-102,381$ & $-102,328$ & $-582,204$ & $-582,152$ & 395,163 & 395,215 \\
\hline$F$ & 986,361 & 986,413 & $-102,385$ & $-102,332$ & $-582,214$ & $-582,152$ & 395,166 & 395,218 \\
\hline Sire\% & 986,336 & 986,389 & $-102,376$ & $-102,333$ & $-582,211$ & $-582,159$ & 395,150 & 395,202 \\
\hline
\end{tabular}

${ }^{1} \mathrm{r}_{\text {chro }}{ }^{2}=\mathrm{r}^{2}$ on chromosome 6 between 40 and $60 \mathrm{Mbp} ; \mathrm{r}_{\text {chr14 }}{ }^{2}=\mathrm{r}^{2}$ on chromosome 14 between 0 and $40 \mathrm{Mbp} ; p=$ allele frequency of the SNP located in the DGAT1 gene; $F=$ pedigree-based inbreeding coefficient; sire $\%=$ percentage of cows with a non-European Union sire; HS = herd size; NRR56 = nonreturn rate after $56 \mathrm{~d}$.

MY, fat\%, and Pro\% (Table 7). Interestingly, also for a random herd allocation, lowest correlations (but also close to 0.90) were estimated for SCS. Also from the RRM, large genetic correlations were identified. Only by trend, genetic correlations were larger for neighboring random herd numbers compared with herd numbers in greater distance. This might be an artifact of random regression modeling with the chosen polynomial structure.

Interestingly, RRM performed better when using continuous genetic or phenotypic herd descriptors compared with genomic herd descriptors. In this regard, and for all test-day traits, Akaike information criteria (AIC) and Schwarz Bayesian information criteria (BIC) were smaller for $F$, sire\%, HS, and NRR56 compared with $\mathrm{r}_{\mathrm{chr} 6}{ }^{2}, \mathrm{r}_{\mathrm{chr} 14}{ }^{2}$, or $p$ (Table 8 ). The AIC and BIC calculations take the number of model parameters into account. Hence, such evaluation criteria also allow RRM-MTRM model comparisons for same traits. Both $\mathrm{AIC}$ and BIC were always smaller for the MTRM, indicating superiority of simpler and more robust geneticstatistical modeling via MTRM for such type of data combined with the herd descriptors used.

\section{CONCLUSIONS}

Although linkage disequilibrium and allele frequencies are characteristics for different populations, breeds, and species, intra-herd means from Holstein cows varied on the genomic scale $\left(\mathrm{r}_{\text {chr6 }}{ }^{2}, \mathrm{r}_{\text {chr14 }}{ }^{2}, p\right)$. Genomic herd differences might be due to different selection strategies after reunification in 1990. For MY, being the trait under intensive selection for decades, heritabilities increased with increasing $\mathrm{r}_{\text {chr6 }}{ }^{2}, \mathrm{r}_{\text {chr14 }}{ }^{2}$, and $p$. Furthermore, an extremely small and a high intra-herd inbreeding coefficient, a high percentage of sires from non-EU countries, a large herd size, and a high intraherd NRR56 contributed to MY heritability increases.
Heritabilities were always lowest and quite constant for SCS in dependency of intra-herd variations. Genetic correlations were lower than 0.80 when considering herds "in great descriptor distance," especially for MY and SCS. Generally, results from the MTRM were in agreement with those from the RRM, but less extreme (closer to 1). Correlations among sire EBV reflected the genetic correlation estimates, suggesting specific sires for specific herd structures. In the present study, we identified the effect of phenotypic, genetic, and genomic herd compositions on genetic correlations. From a practical perspective, we suggest utilization of a broad herd pattern when designing cow calibration groups to avoid possible $\mathrm{G} \times \mathrm{E}$ due to specific herd architectures.

\section{ACKNOWLEDGMENTS}

The authors gratefully acknowledge funding from the German Federal Ministry of Education and Research (BMBF) and from the Förderverein Bioökonomieforschung e.V. (FBV)/German Holstein Association (DHV) for the collaborative project "KMU-innovativ-10: Kuh$\mathrm{L}$ - cow calibration groups for the implementation of selection strategies based on high-density genotyping in dairy cattle," grant no. 031A416C.

\section{REFERENCES}

Bastiaansen, J. W. M., A. Coster, M. P. L. Calus, J. A. M. van Arendonk, and H. Bovenhuis. 2012. Long-term response to genomic selection: Effects of estimation method and reference population structure for different genetic architectures. Genet. Sel. Evol. 44:3.

Bishop, M. 1964. Paternal contribution to embryonic death. J. Reprod. Fertil. 7:383-396.

Boettcher, P. J., J. Fatehi, and M. M. Schutz. 2003. Genotype $\times$ environment interactions in conventional versus pasture-based dairies in Canada. J. Dairy Sci. 86:383-389.

Brügemann, K., E. Gernand, U. U. von Borstel, and S. König. 2011. Genetic analyses of protein yield in dairy cows applying random regression models with time-dependent and temperature $\mathrm{x}$ humidity-dependent covariates. J. Dairy Sci. 94:4129-4139. 
Brügemann, K., E. Gernand, U. U. von Borstel, and S. König. 2013. Application of random regression models to infer the genetic background and phenotypic trajectory of binary conception rate by alterations of temperature $\times$ humidity indices. Livest. Sci. 15:389396

Calus, M., and R. F. Veerkamp. 2003. Estimation of environmental sensitivity of genetic merit for milk production traits using a random regression model. J. Dairy Sci. 86:3756-3764.

Cassell, B. G., V. Adamec, and R. E. Pearson. 2003. Maternal and fetal inbreeding depression for 70-day nonreturn and calving rate in Holsteins and Jerseys. J. Dairy Sci. 86:2977-2983.

Clark, S. A., J. M. Hickey, H. D. Daetwyler, and J. H. van der Werf. 2012. The importance of information on relatives for the prediction of genomic breeding values and the implications for the makeup of reference data sets in livestock breeding schemes. Genet. Sel. Evol. 44:4.

Falconer, D. S., and T. F. C. Mackay. 1996. Introduction to Quantitative Genetics. 4th ed. Longman, Essex, UK.

Gernand, E., and S. König. 2014. Random regression test-day model for clinical mastitis: Genetic parameters, model comparison, and correlations with indicator traits. J. Dairy Sci. 97:3953-3963.

Goddard, M. 2009. Genomic selection: prediction of accuracy and maximisation of long term response. Genetica 136:245-257.

Grisart, B., W. Coppieters, F. Farnir, L. Karim, C. Ford, P. Berzi, N. Cambisano, M. Mni, S. Reid, P. Simon, R. Spelman, M. Georges, and R. Snell. 2002. Positional candidate cloning of a QTL in dairy cattle: Identification of a missense mutation in the bovine DGAT1 gene with major effect on milk yield and composition. Genome Res. 12:222-231.

Grishkevich, V., and I. Yanai. 2013. The genomic determinants of genotype $\times$ environment interactions in gene expression. Trends Genet. 29:479-487.

Habier, D., J. Tetens, F.-R. Seefried, P. Lichtner, and G. Thaller. 2010. The impact of genetic relationship information on genomic breeding values in German Holstein cattle. Genet. Sel. Evol. 42:5.

Hammond, J. 1947. Animal breeding in relation to nutrition and environmental conditions. Biol. Rev. Camb. Philos. Soc. 22:195-213.

Hayes, B. J., M. Carrick, P. Bowman, and M. E. Goddard. 2003. Genotypexenvironment interaction for milk production of daughters of Australian dairy sires from test-day records. J. Dairy Sci. $86: 3736-3744$.

Henderson, C. R. 1964. Selecting the young sire to sample in artificial insemination. J. Dairy Sci. 47:439-441.

Hill, W. G., and A. Robertson. 1968. Linkage disequilibrium in finite populations. Theor. Appl. Genet. 38:226-231.

Jaeger, M., K. Brügemann, and S. König. 2016. Genetic relationships and trait comparison between and within selected lines of local dual purpose cattle. S. 307 in Book of Abstracts EAAP - 67th Anuual Meeting, 29 Aug-2 Sept 2016, Belfast, UK

Jiang, L., J. Liu, D. Sun, P. Ma, X. Ding, Y. Yu, and Q. Zhang. 2010. Genome wide association studies for milk production traits in Chinese Holstein population. PLoS One 5:e13661.

Khatkar, M. S., P. C. Thomson, I. Tammen, and H. W. Raadsma. 2004. Quantitative trait loci mapping in dairy cattle: review and meta-analysis. Genet. Sel. Evol. 36:163-190.

König, S. 2017. Genetic correlations for protein yield from different regions: Impact of sire categories. Internal Seminar, Justus-LiebigUniversity Gießen. November 21.

König, S., Y. M. Chang, U. U. von Borstel, D. Gianola, and H. Simianer. 2008. Genetic and phenotypic relationships among milk urea nitrogen, fertility, and milk yield in Holstein cows. J. Dairy Sci. 91:4372-4382.

König, S., G. Dietl, I. Raeder, and H. H. Swalve. 2005. Genetic relationships for dairy performance between large-scale and smallscale farm conditions. J. Dairy Sci. 88:4087-4096.

König, S., and H. Simianer. 2006. Approaches to the management of inbreeding and relationship in the German Holstein dairy cattle population. Livest. Sci. 103:40-53.

König, S., H. Simianer, and H. H. Swalve. 2002. Genetic relationships between dairy performance under large-scale farm and family farm conditions estimated from different groups of common sires. Proceedings of the 7th World Congress on Genetics Applied to Livestock Production, 19.08.-23.08.2002, Montpellier, France. Book of abstracts.

Kühn, C., G. Thaller, A. Winter, O. R. P. Bininda-Emonds, B. Kaupe, G. Erhardt, J. Bennewitz, M. Schwerin, and R. Fries. 2004. Evidence for multiple alleles at the DGAT1 locus better explains a quantitative trait locus with major effect on milk fat content in cattle. Genetics 167:1873-1881.

Madsen, P., and J. Jensen. 2013. A user's guide to DMU. A package for analysing multivariate mixed models. Version 6 , release 5.2 University of Aarhus, Tjele, Denmark.

Miglior, F., B. L. Muir, and B. J. van Doormaal. 2005. Selection indices in Holstein cattle of various countries. J. Dairy Sci. 88:1255-1263.

Miglior, F., B. Szkotnicki, and E. B. Burnside. 1992. Analysis of levels of inbreeding and inbreeding depression in Jersey cattle. J. Dairy Sci. 75:1112-1118.

Minozzi, G., E. L. Nicolazzi, A. Stella, S. Biffani, R. Negrini, B. Lazzari, P. Ajmone-Marsan, and J. L. Williams. 2013. Genome wide analysis of fertility and production traits in Italian Holstein cattle. PLoS One 8:e80219.

Mulder, H. A., A. F. Groen, G. de Jong, and P. Bijma. 2004. Genotypexenvironment interaction for yield and somatic cell score with automatic and conventional milking systems. J. Dairy Sci. $87: 1487-1495$.

Naderi, S., T. Yin, and S. König. 2016. Random forest estimation of genomic breeding values for disease susceptibility over different disease incidences and genomic architectures in simulated cow calibration groups. J. Dairy Sci. 99:7261-7273.

Nauta, W. J., R. F. Veerkamp, E. W. Brascamp, and H. Bovenhuis. 2006. Genotype by environment interaction for milk production traits between organic and conventional dairy cattle production in The Netherlands. J. Dairy Sci. 89:2729-2737.

Nguyen, T. T. T., P. J. Bowman, M. Haile-Mariam, J. E. Pryce, and B. J. Hayes. 2016. Genomic selection for tolerance to heat stress in Australian dairy cattle. J. Dairy Sci. 99:2849-2862.

Ojango, J., and G. Pollott. 2002. The relationship between Holstein bull breeding values for milk yield derived in both the UK and Kenya. Livest. Prod. Sci. 74:1-12.

Pimentel, E. C., M. Wensch-Dorendorf, S. König, and H. H. Swalve. 2013. Enlarging a training set for genomic selection by imputation of un-genotyped animals in populations of varying genetic architecture. Genet. Sel. Evol. 45:12.

Powell, R. L., H. D. Norman, and A. H. Sanders. 2003. Progeny testing and selection intensity for Holstein bulls in different countries. J. Dairy Sci. 86:3386-3393

Pszczola, M., T. Strabel, H. A. Mulder, and M. P. L. Calus. 2012 Reliability of direct genomic values for animals with different relationships within and to the reference population. J. Dairy Sci. 95:389-400.

Purcell, S., B. Neale, K. Todd-Brown, L. Thomas, M. A. R. Ferreira, D. Bender, J. Maller, P. Sklar, P. I. W. de Bakker, M. J. Daly, and P. C. Sham. 2007. PLINK: A tool set for whole-genome association and population-based linkage analyses. Am. J. Hum. Genet. $81: 559-575$.

Qanbari, S., E. C. G. Pimentel, J. Tetens, G. Thaller, P. Lichtner, A. R. Sharifi, and H. Simianer. 2010. The pattern of linkage disequilibrium in German Holstein cattle. Anim. Genet. 41:346-356.

Robertson, A. 1959. The sampling variance of the genetic correlation coefficient. Biometrics 15:469.

Sargolzaei, M., H. Iwaisaki, and J. J. Colleau. 2006. CFC: A tool for monitoring genetic diversity. 27-28 in Proc. 8th World Congress on Genetics Applied to Livestock Production, Belo Horizonte, Minas Gerais, Brazil, 13-18 August, 2006.

Schennink, A., W. M. Stoop, M. H. P. W. Visker, J. M. L. Heck, H. Bovenhuis, J. J. van der Poel, H. J. F. van Valenberg, and J. A. M. van Arendonk. 2007. DGAT1 underlies large genetic variation in milk-fat composition of dairy cows. Anim. Genet. 38:467-473.

Schierenbeck, S., F. Reinhardt, R. Reents, H. Simianer, and S. König. 2011. Identification of informative cooperator herds for progeny testing based on yield deviations. J. Dairy Sci. 94:2071-2082. 
Streit, M., F. Reinhardt, G. Thaller, and J. Bennewitz. 2013. Genome-wide association analysis to identify genotype $\mathrm{x}$ environment interaction for milk protein yield and level of somatic cell score as environmental descriptors in German Holsteins. J. Dairy Sci. 96:7318-7324.

Thaller, G., W. Krämer, A. Winter, B. Kaupe, G. Erhardt, and R. Fries. 2003. Effects of variants on milk production traits in German cattle breeds. J. Anim. Sci. 81:1911-1918.

Thompson, J. R., R. W. Everett, and N. L. Hammerschmidt. 2000 Effects of inbreeding on production and survival in Holsteins. J. Dairy Sci. 83:1856-1864.

Tsuruta, S., D. A. L. Lourenco, I. Misztal, and T. J. Lawlor. 2015. Genotype by environment interactions on culling rates and 305day milk yield of Holstein cows in 3 US regions. J. Dairy Sci. 98:5796-5805.

van Binsbergen, R., R. F. Veerkamp, and M. P. L. Calus. 2012. Makeup of the genetic correlation between milk production traits us- ing genome-wide single nucleotide polymorphism information. J Dairy Sci. 95:2132-2143.

Veerkamp, R. F., H. A. Mulder, R. Thompson, and M. P. L. Calus. 2011. Genomic and pedigree-based genetic parameters for scarcely recorded traits when some animals are genotyped. J. Dairy Sci. 94:4189-4197.

Via, S., and R. Lande. 1985. Genotype-environment interaction and the evolution of phenotypic plasticity. Evolution 39:505.

Yin, T., and S. König. 2016. Genomics for phenotype prediction and management purposes. Anim. Front. 6:5.

Yin, T., E. Pimentel, U. König v. Borstel, and S. König. 2014. Strategy for the simulation and analysis of longitudinal phenotypic and genomic data in the context of a temperature $\times$ humidity-dependent covariate. J. Dairy Sci. 97:2444-2454. 